\title{
Different characteristics of new particle formation between urban and deciduous forest sites in Northern Japan during the summers of 2010-2011
}

\author{
J. Jung ${ }^{1, *}$, Y. Miyazaki ${ }^{1}$, and K. Kawamura ${ }^{1}$ \\ ${ }^{1}$ Institute of Low Temperature Science, Hokkaido University, Sapporo 060-0819, Japan \\ * now at: Center for Gas Analysis, Korea Research Institute of Standards and Science, Daejeon 305-340, Korea \\ Correspondence to: K. Kawamura (kawamura@lowtem.hokudai.ac.jp)
}

Received: 19 March 2012 - Published in Atmos. Chem. Phys. Discuss.: 6 June 2012

Revised: 19 November 2012 - Accepted: 21 November 2012 - Published: 4 January 2013

\begin{abstract}
To investigate new particle formation (NPF) events in urban and forest environments, number size distributions of ultrafine particles were measured at an urban site and a deciduous forest site in Sapporo, Northern Japan, during the summers of 2011 and 2010, respectively. The burst of nucleation mode particles at the urban site typically started in the morning (07:00-11:30 local time, LT) with simultaneous increases in $\mathrm{SO}_{2}$ and $\mathrm{O}_{3}$ concentrations and the UV index under clear (sunny) weather conditions. The growth rates of nucleated particles at the urban site ranged from 5.0 to $7.8 \mathrm{~nm} \mathrm{~h}^{-1}$ with an average of $6.3 \pm 1.1 \mathrm{~nm} \mathrm{~h}^{-1}$. NPF events at the urban site were separated into events with or without subsequent particle growth after the burst of nucleation mode particles. This division was found to relate to prevailing wind direction because the subsequent growth of freshly nucleated particles typically occurred when wind direction shifted to northwesterly (from residential and public park areas), whereas it did not occur under southeasterly winds (from the downtown area). During the periods with NPF events, elevated concentrations of non-methane hydrocarbons (NMHC) were obtained under conditions of northwesterly winds when compared to southeasterly winds, whereas no difference in $\mathrm{SO}_{2}$ levels was recorded. These results suggest that variations in NMHC concentration may play an important role in the growth of freshly nucleated particles at the urban site. The burst of nucleation mode particles at the forest site typically started around noon (10:30-14:30 LT), which was 3-4h later than that at the urban site. Interestingly, at the forest site the burst of nucleation mode particles usually started when air masses originating from urban Sapporo arrived at the forest
\end{abstract}

site. The present study indicates that the inflow of these urban air masses acted as a trigger for the initiation of the burst of nucleation mode particles in the deciduous forest.

\section{Introduction}

New particle formation (NPF), an important source of ambient aerosols, is frequently observed occurring worldwide (Kulmala et al., 2004; Mikkonen et al., 2006; Holmes, 2007; Bzdek and Johnston, 2010; Hallar et al., 2011; Pryor et al., 2011). NPF events usually occur during daytime when the pre-existing particle mass concentration is low under sunny and dry conditions (Birmili and Wiedensohler, 2000; Dunn et al., 2004; Stanier et al., 2004; Wu et al., 2007; Hamed et al., 2011; Pryor et al., 2011). Nuclei clusters of approximately $1-2 \mathrm{~nm}$ are commonly formed via homogeneous nucleation involving binary mixtures of water and sulfuric acid (Jaecker-Voirol and Mirabel, 1989), homogeneous ternary (water-sulfuric acid-ammonia) nucleation (Korhonen et al., 1999), and ion-induced nucleation (Raes and Janssens, 1985; Yu and Turco, 2000).

It is assumed that organic vapors are required to promote the growth of nuclei clusters into quasi-stable aerosol particles larger than $3 \mathrm{~nm}$ by several possible mechanisms: heterogeneous nucleation of water-insoluble organic vapors on the clusters, activation of the clusters for condensation of watersoluble organic vapors, and chemical reactions on the surfaces of small clusters (Jang and Kamens, 2001; Zhang and Wexler, 2002; O’Dowd et al., 2002; Kulmala, 2003). On the 
other hand, in areas with high $\mathrm{SO}_{2}$ emissions, particle growth is dominated by sulfuric acid (Petäjä et al., 2007; Yue et al., 2010; Pryor et al., 2011). Pryor et al. (2011) showed that a large portion of sub-32 nm particle mass during the periods with NPF events was attributed to ammonium and sulfate. Nucleated particles may grow to larger particles $(>100 \mathrm{~nm})$ within the following two days (Kulmala et al., 2004) and thus may influence regional climate by enhancing the concentration of cloud condensation nuclei (CCN) and also by directly scattering solar radiation.

In the urban atmosphere, where the surface area of preexisting particles is generally high due to elevated emissions from traffic, NPF is less likely owing to the condensation sink created by pre-existing particles. Yue et al. (2009) found that NPF events in the Beijing urban atmosphere usually occurred under low number concentrations of Aitken and accumulation mode particles, when clean air masses dominated at the measurement site. Gao et al. (2009) showed that an intense production of sulfuric acid from the photo-oxidation of $\mathrm{SO}_{2}$ enhanced NPF in the suburban area of the Yangtze River delta. Yue et al. (2010) observed that the condensation and neutralization of sulfuric acid, together with coagulation, caused the growth of freshly nucleated particles during sulfur-rich periods, whereas organic compounds were responsible for particle growth during sulfur-poor periods. Cheung et al. (2011) reported that freshly nucleated particles at an urban site in Brisbane, Australia, showed different growth patterns depending on the type of air mass present at the measurement site. The growth of freshly nucleated particles at three measurement sites in southern Indiana was only observed under clear weather conditions in the morning when fractional cloud cover was less than $30 \%$ (Pryor et al., 2011).

NPF also has been observed at remote high elevation sites (Nishita et al., 2008; Venzac et al., 2008; Boulon et al., 2010, 2011; Hallar et al., 2011). Nucleation frequency varied depending on geographical locations: $17 \%$ of measurement days at Mount Norikura (2770 m a.s.l.) in Japan (Nishita et al. 2008), $17.5 \%$ at Jungfraujoch (3580 $\mathrm{m}$ a.s.1.) in the Swiss Alps (Boulon et al., 2010), 20.8\% at the Opme station (660 $\mathrm{m}$ a.s.l.) and $35.9 \%$ at the puy de Dôme research station (1465 m a.s.l.) in central France (Boulon et al., 2011), $35 \%$ at the Nepal Climate Observatory (5079 m a.s.1.) (Venzac et al., 2008), and $52 \%$ at Storm Peak Laboratory in Colorado (3210 m a.s.l.) (Hallar et al., 2011). On the basis of long-term observation from 2001 to 2009 at the Storm Peak Laboratory, Hallar et al. (2011) showed that high ultraviolet (UV) radiation accelerate NPF. However, NPF at the Storm Peak Laboratory in Colorado was not related to $\mathrm{O}_{3}$ concentration and pre-existing aerosol surface area (Hallar et al., 2011).

NPF and subsequent particle growth from biogenic emissions of volatile organic compounds (VOCs) in forested areas are an important source of CCN. Although such NPF events have been widely observed, their formation mechanisms over forests are poorly understood. The formation of biogenic sec- ondary organic aerosols (SOA) in forested areas is enhanced by the inflow of anthropogenic pollutants (Weber et al., 2007; Boy et al., 2008; Kanawade et al., 2011; Neitola et al., 2011). These results are consistent with the recent laboratory studies, which showed that the formation of biogenic SOA can be promoted by anthropogenic influences (Zhang et al., 2009; Froyd et al., 2010; Hoyle et al., 2011). Froyd et al. (2010) and Zhang et al. (2009) reported that the interaction between sulfuric acid and biogenic organic acids enhances both nucleation and the initial growth of nano-size particles. Metzger et al. (2010) also reported that organic compounds together with sulfuric acid likely initiate the nucleation process.

Isoprene fluxes over the Amazonian rainforest are almost 10 times higher than $\alpha$-pinene fluxes (Rinne et al., 2002). Isoprene emissions from mixed deciduous forest in the northern United States are particularly large ( $>95 \%$ of the total terpenoid emission) compared to emissions of monoterpenes and sesquiterpenes (Ortega et al., 2007). However, concentrations of monoterpenes in coniferous boreal forest in Finland are $\sim 5$ times higher than concentrations of isoprene (Spirig et al., 2004). Although NPF events have been observed in European coniferous forests, including Finland's boreal forest (e.g., Kulmala et al., 2004) and coniferous forest in Germany (Held et al., 2004), NPF events have not been reported in the mixed deciduous forests of the Amazon and the northern United States, where emissions of biogenic isoprene are abundant (Martin et al., 2010; Kanawade et al., 2011). Therefore more research is required regarding the mechanisms of NPF in a deciduous forest.

To better understand NPF events and the mechanisms of subsequent particle growth, we continuously measured particle number size distributions using a scanning mobility particle sizer (SMPS) at two atmospheric sites: one in an urban area and the other in a broadleaf deciduous forest in Sapporo, northern Japan. The factors controlling NPF and the subsequent particle growth are investigated. Here, we report NPF events at the two sites and discuss in detail the impact of anthropogenic emissions on NPF in a deciduous forest.

\section{Experimental}

\subsection{Description of the measurement sites}

Particle number size distributions were measured at an urban site (between 21 July and 9 August 2011) and at a deciduous forest site (between 10 and 26 August 2010) in Sapporo, northern Japan. An area map of the measurement sites is shown in Fig. 1. The time shown in this study represents local time in Japan (LT) (GMT + 09:00).

\subsubsection{Urban site}

The city of Sapporo (population 1.9 million, area $1121 \mathrm{~km}^{2}$ ) is located in the western part of Hokkaido, the northernmost main island of Japan (Fig. 1). Sapporo is surrounded by 


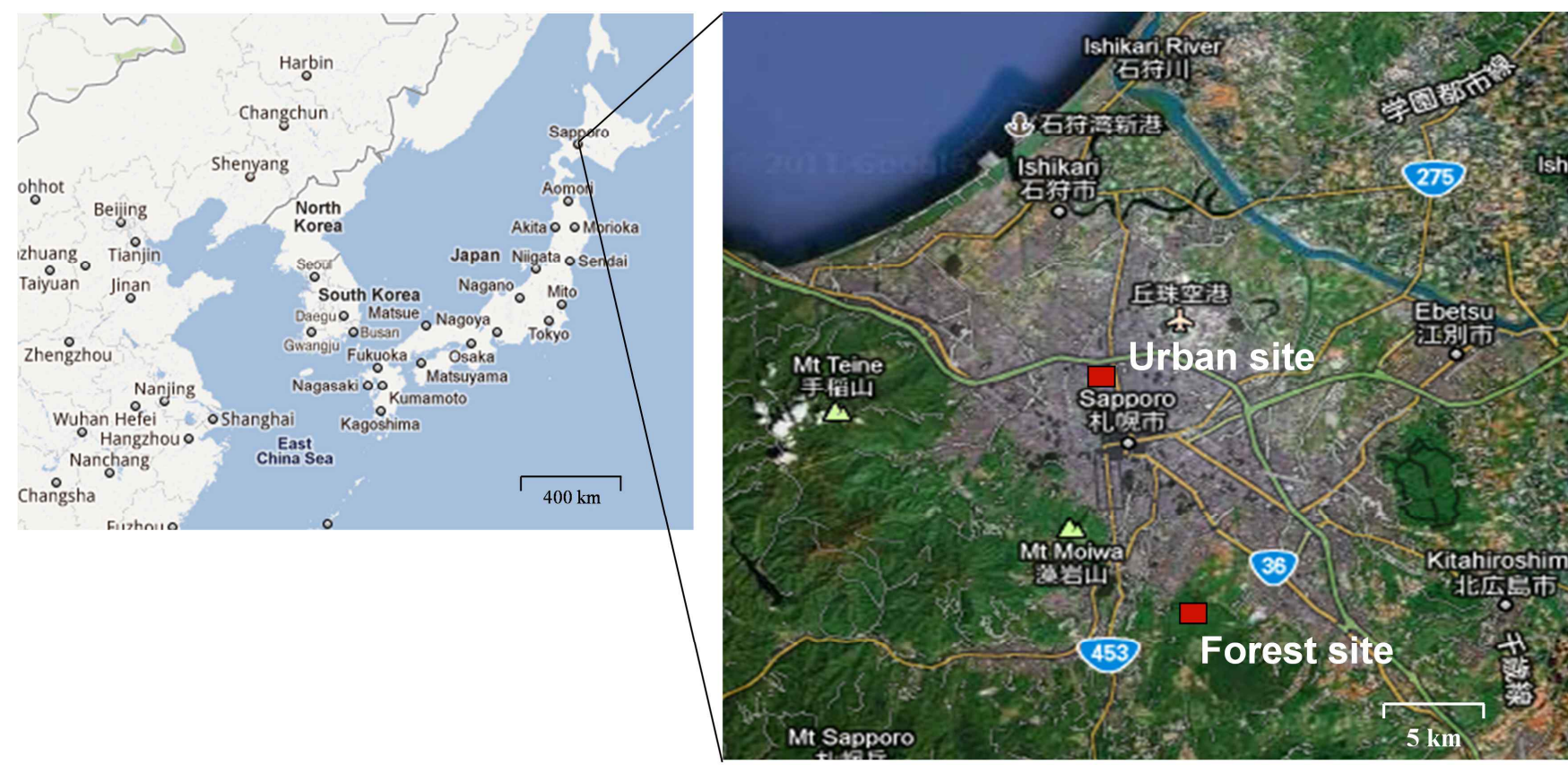

Fig. 1. Image map of the measurement sites (Google Map and Google Earth imagery (@ Google Inc.)). The urban site is located at the north campus of Hokkaido University $\left(43^{\circ} 3^{\prime} 56^{\prime \prime} \mathrm{N}, 141^{\circ} 21^{\prime} 27^{\prime \prime} \mathrm{E}\right)$ in the northwest of downtown Sapporo, Japan. The forest site is located at the Sapporo forest meteorology research site $\left(42^{\circ} 59^{\prime} 13^{\prime \prime} \mathrm{N}, 141^{\circ} 23^{\prime} 53^{\prime \prime} \mathrm{E}\right)$ in the western part of Hokkaido. The distance between the two sites is $\sim 11.5 \mathrm{~km}$.

forested areas with the exception of its northwestern border. The urban site was located at the north campus of Hokkaido University $\left(43^{\circ} 3^{\prime} 56^{\prime \prime} \mathrm{N}, 141^{\circ} 21^{\prime} 27^{\prime \prime} \mathrm{E}\right)$ in the northwest of downtown Sapporo (Aggarwal and Kawamura, 2009; Kitamori et al., 2009). The campus is surrounded mainly by residential areas, and the urban center is located $\sim 2 \mathrm{~km}$ south of university campus. Hourly averaged total suspended particle (TSP) mass concentration, atmospheric concentrations of non-methane hydrocarbons (NMHC) and the criteria pollutants such as $\mathrm{O}_{3}, \mathrm{NO}_{2}$, and $\mathrm{SO}_{2}$ close to the urban site were obtained from the Ministry of the Environment of Japan at the Sapporo observatory (http://soramame.taiki.go.jp/). $\mathrm{O}_{3}$, $\mathrm{NO}_{2}$, and $\mathrm{SO}_{2}$ data in ppb level are rounded up the first decimal number and available at the web site of the Sapporo observatory.

Aggarwal and Kawamura (2009) found that photochemical aging was an important factor controlling the watersoluble property of organic aerosols at the same Sapporo urban site during the spring and early summer of 2005, based on different organic tracers and ionic marker species in aerosol samples. They demonstrated that organic carbon (OC) loading may be governed by aerosol sources and source regions, but the water-soluble OC (WSOC) fraction of OC was considerably influenced by aerosol aging. On the basis of the size-segregated chemical composition of atmospheric aerosols, Agarwal et al. (2010) reported that most of the diacids, ketoacids, $\alpha$-dicarbonyls, levoglucosan, WSOC, and inorganic ions (i.e., $\mathrm{SO}_{4}^{2-}, \mathrm{NH}_{4}^{+}$, and $\mathrm{K}^{+}$) were enriched in fine particles $\left(\mathrm{PM}_{1.1}\right)$ collected at the same urban site in Sapporo during the summer of 2005. Biomass burnings in the Siberian region were found to significantly influence the chemical composition of carbonaceous particles in the Sapporo urban aerosol during the summer of 2005 (Agarwal et al., 2010).

\subsubsection{Forest site}

The forest site is located at the Hokkaido Research Center, Forestry and Forest Products Research Institute in Sapporo $\left(42^{\circ} 59^{\prime} 13^{\prime \prime} \mathrm{N}, 141^{\circ} 23^{\prime} 53^{\prime \prime} \mathrm{E}\right)$ (Fig. 1). This site is characterized by a secondary hardwood forest located in the western part of Hokkaido. The northern border of the forest faces urban Sapporo, which is $\sim 2 \mathrm{~km}$ away from the experiment site. As described by Miyazaki et al. (2012a), the experimental site is covered with broadleaf deciduous trees in a transitional stage from mature birch (Betula platyphylla) to climax species, mainly Mizunara oak (Quercus crispula). Needleleaf evergreen trees are also present in the surrounding area. The understory consists of evergreen Sasa bamboo (Sasa kurilensis and Sasa senanensis), which extensively covers the ground surface. The $\mathrm{O}_{3}$ concentration was continuously measured at the forest site. Additionally, the $\mathrm{SO}_{2}$ concentration was obtained from an urban observatory in Sapporo; this observatory is located $\sim 5 \mathrm{~km}$ north of the forest site and is operated by the Ministry of the Environment of Japan (http://soramame.taiki.go.jp/). 
Miyazaki et al. (2012a) investigated the seasonal changes in water-soluble organic carbon (WSOC) in aerosols from the same deciduous forest site in 2009 and 2010 based on the analyses of organic chemical composition and the stable carbon isotopic composition of WSOC. They found that biogenic secondary organic aerosols (BSOAs) accounted for $\sim 40 \%$ of the highest concentrations of WSOC in early summer and mostly consisted of $\alpha-/ \beta$-pinene secondary organic aerosols. They also found that the isoprene SOA tracers such as 2-methyltetrols and $\mathrm{C}_{5}$-alkene triols increased sharply during the summer and fall of 2010 (July-October). However, properties of ultrafine particles such as their generation mechanism and growth characteristics have never been studied in this forest site.

\subsection{Particle number size distribution}

A scanning mobility particle sizer (SMPS) was deployed at the two sites to measure number size distributions of ultrafine particles. A nano-differential mobility analyzer (nanoDMA) (TSI, model 3085) was used at the urban site whereas a long-DMA (TSI, model 3081) was used at the forest site. The nano-DMA SMPS consisted of an electrostatic classifier (TSI, model 3080), a condensation particle counter (CPC) (TSI, model 3775) and the nano-DMA. The longDMA SMPS consisted of the same electrostatic classifier and CPC and the long-DMA.

The instrument specification for the CPC indicated a $90 \%$ counting efficiency for a particle diameter of $7 \mathrm{~nm}$. Thus, particle size ranging from $7 \mathrm{~nm}$ to $165 \mathrm{~nm}$ was measured using the nano-DMA SMPS at the urban site. However, because the lowest separation size of the long-DMA is $\sim 14 \mathrm{~nm}$, particle size ranging from $14 \mathrm{~nm}$ to $750 \mathrm{~nm}$ was measured using the long-DMA SMPS at the forest site.

Sample inlets were installed at $\sim 5 \mathrm{~m}$ and $\sim 15 \mathrm{~m}$ heights above ground level at the urban and forest sites, respectively. Ambient air was drawn through a $\mathrm{PM}_{1}$ cyclone inlet with a flow rate of $16.7 \mathrm{~L}$ per minute (LPM). An aliquot (0.3 LPM) of the sampled air flow was separated and dried to a relative humidity (RH) $<5 \%$ using two diffusion dryers before being introduced to the SMPS. Sample and sheath flow rates of the DMA were set to 0.3 LPM and 3 LPM, respectively. The SMPS was calibrated using a polystyrene latex (PSL) standard prior to field measurements. Two PSL standards were purchased from the JSR Co. (product numbers sc-0070-D for the $70 \mathrm{~nm}$ standard and sc-0120-D for the $123 \mathrm{~nm}$ standard). The $70 \mathrm{~nm}$ and $123 \mathrm{~nm}$ diameters of the PSL standards were measured as $70.4 \pm 0.12 \mathrm{~nm}$ and $123.2 \pm 0.22 \mathrm{~nm}$, respectively.

Mode peak diameter (Mode $\mathrm{D}_{p}$ ) was obtained from a log-normal Gaussian fit of particle number size distribution smaller than $100 \mathrm{~nm}$. The Mode $\mathrm{D}_{p}$ was used to calculate the growth rate of nucleated particles. In this study, the size distribution data were classified into three groups: ultrafine particles (UFP) $\left(\mathrm{D}_{p}<100 \mathrm{~nm}\right)$, Aitken mode parti- cles $\left(30 \mathrm{~nm}<\mathrm{D}_{p}<100 \mathrm{~nm}\right)$, and nucleation mode particles $\left(\mathrm{D}_{p}<30 \mathrm{~nm}\right)$. Because of the different lowest detectable sizes of the SMPS at the urban and forest sites, total number concentrations of nucleation mode particles at the urban and forest sites were calculated by integrating particle number concentrations from $7 \mathrm{~nm}$ to $30 \mathrm{~nm}\left(N_{\text {nuc_urban }}\right)$ and from $14 \mathrm{~nm}$ to $30 \mathrm{~nm}$ ( $\left.N_{\text {nuc_forest }}\right)$, respectively. Similarly, total number concentrations of UFP at the urban and forest sites were calculated by integrating particle number concentrations from $7 \mathrm{~nm}$ to $100 \mathrm{~nm}\left(N_{\text {UFP_urban }}\right)$ and from $14 \mathrm{~nm}$ to $100 \mathrm{~nm}$ ( $\left.N_{\text {UFP_forest }}\right)$, respectively. Total number concentrations of Aitken mode particles $\left(N_{\text {Aitken }}\right)$ at both sites were calculated by integrating particle number concentrations from $30 \mathrm{~nm}$ to $100 \mathrm{~nm}$.

\subsection{Meteorological conditions}

Meteorological data (temperature, relative humidity (RH), wind direction, wind speed, rainfall, and UV index) during the urban campaign were obtained from the Japan Meteorological Agency in Sapporo $\left(43^{\circ} 3.6^{\prime} \mathrm{N}, 141^{\circ} 19.7^{\prime} \mathrm{E}, 17 \mathrm{~m}\right.$ above ground level), which is located at $\sim 2.6 \mathrm{~km}$ south of the urban site. The UV index was formulated using the International Commission on Illumination (CIE) reference action spectrum for UV-induced erythema on human skin (World Health Organization, 2002). The UV index was calculated using measured solar irradiance from $250 \mathrm{~nm}$ to $400 \mathrm{~nm}$ and the erythema reference action spectrum and is a unitless quantity. The UV index used definitions of as low $(<2)$, moderate (3-5), high (6-7), very high $(8-10)$, and extreme $(>11)$. Local meteorological parameters at the forest site were measured using an automatic weather transmitter (WXT-510, Vaisala) (Miyazaki et al., 2012a). Additionally, meteorological data for urban Sapporo during the forest campaign were also obtained from the Japan Meteorological Agency in Sapporo, which is located at $\sim 9.5 \mathrm{~km}$ north of the forest site. Hourly averaged data were used in this study. Average ambient temperature during the urban campaign ranged from $14^{\circ} \mathrm{C}$ to $31^{\circ} \mathrm{C}$ with an average of $23 \pm 3{ }^{\circ} \mathrm{C}$, which was very similar to temperatures during the forest campaign (range: $16-29^{\circ} \mathrm{C}$, avg.: $22 \pm 3^{\circ} \mathrm{C}$ ) (Table 1). However, a slightly lower RH was recorded during the urban campaign (range: $39-92 \%$, avg.: $72 \pm 11 \%$ ) compared to the $\mathrm{RH}$ recorded during the forest campaign (range: 45-97\%, avg.: $86 \pm 10 \%$ ) (Table 1). Most measurements were carried out under the clear weather conditions, although a number of rainfall events occurred (see Table 1).

The dominant local wind directions during the urban campaign varied between southeasterly and northwesterly with an average wind speed of $3 \pm 2 \mathrm{~m} \mathrm{~s}^{-1}$ (range: $0-11 \mathrm{~m} \mathrm{~s}^{-1}$ ) (Fig. 2a and Table 1). During the forest campaign, the dominant local wind directions were southwesterly with an average wind speed of $0.5 \pm 0.4 \mathrm{~m} \mathrm{~s}^{-1}$ (range: $0.1-3.1 \mathrm{~m} \mathrm{~s}^{-1}$ ) (Fig. $2 \mathrm{~b}$ and Table 1). Because the urban site was surrounded by forested areas (Fig. 1), air masses originating from the 
Table 1. Summary of meteorological data at an urban site and a deciduous forest site in Sapporo, northern Japan, during the measurement periods.

\begin{tabular}{llllll}
\hline Site & Period & $\begin{array}{l}\text { Temperature } \\
\left({ }^{\circ} \mathrm{C}\right)\end{array}$ & $\begin{array}{l}\text { Relative humidity } \\
(\mathrm{RH})(\%)\end{array}$ & $\begin{array}{l}\text { Wind speed } \\
\left(\mathrm{m} \mathrm{s}^{-1}\right)\end{array}$ & Rainfall event \\
\hline Urban site & 21 Jul-9 Aug 2011 & $14-31(23 \pm 3)$ & $39-92(72 \pm 11)$ & $0-10(3 \pm 2)$ & $\begin{array}{l}\text { 27 Jul, 13:00-14:00 LT, } \\
\text { 5 Aug, 16:00 LT, 6 Aug, 16:00 LT }\end{array}$ \\
$\begin{array}{l}\text { Deciduous } \\
\text { forest site }\end{array}$ & 10-26 Aug 2010 & $16-29(22 \pm 3)$ & $45-97(86 \pm 10)$ & $0.1-3.1(0.5 \pm 0.4)$ & $\begin{array}{l}\text { 11 Aug, 06:00-08:00 LT, } \\
\text { 11 Aug, 20:00-12 Aug, 13:00 LT, } \\
\end{array}$ \\
& & & & $\begin{array}{l}\text { 23 Aug, 10:00-15:00 LT, 24 Aug, } \\
\text { 03:00-05:00 LT }\end{array}$ \\
\hline
\end{tabular}

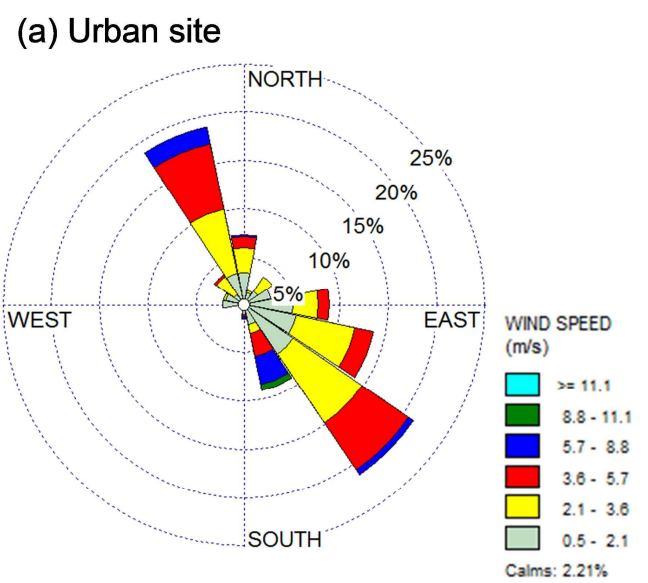

(b) Forest site

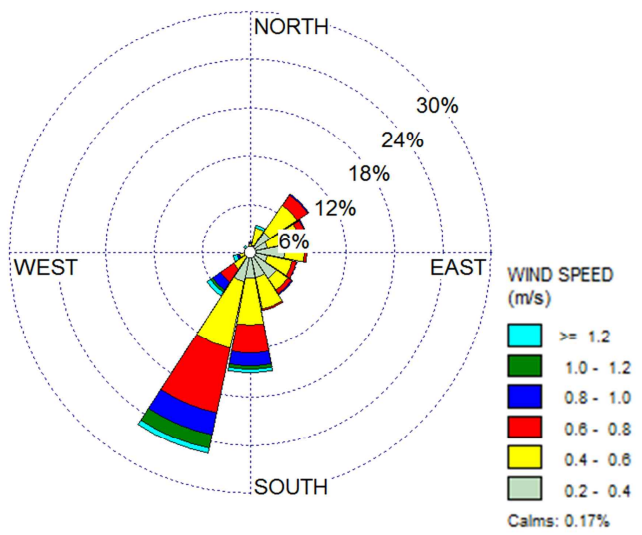

Fig. 2. Observed frequencies of local wind direction with wind speed at (a) the urban site during 21 July-9 August 2011 and (b) the forest site during 10-26 August 2010.

surrounding forests may influence the urban site under southeasterly wind conditions (Fig. 2a). In a similar manner, because the forest site is located $\sim 2 \mathrm{~km}$ south of the southern border of urban Sapporo (Fig. 1), air masses originating from urban Sapporo may influence the forest site under northeasterly wind conditions (Fig. 2b).

Because two campaigns were conducted in different years (2011 for the urban campaign and 2010 for the forest campaign), meteorological parameters at the forest site in 2010 and 2011 were compared to determine if substantial differences had occurred. Average ambient temperature and RH at the forest site during 10-26 August 2011 were recorded as $21 \pm 3{ }^{\circ} \mathrm{C}$ (range: $15-31^{\circ} \mathrm{C}$ ) and $82 \pm 12 \%$ (range: $42-$ $95 \%$ ) respectively, which are very similar to the values measured at the forest site during 10-26 August 2010. Very similar UV-B intensity and local wind speed measurements were also obtained at the forest site during 10-26 August 2011. In the 2010 measurement period average UV-B intensity was $0.06 \pm 0.13 \mathrm{~W} \mathrm{~m}^{-2}$ (range: $0-0.84 \mathrm{~W} \mathrm{~m}^{-2}$ ) and average wind speed was $0.5 \pm 0.4 \mathrm{~m} \mathrm{~s}^{-1}$ (range: $0.1-3.1 \mathrm{~m} \mathrm{~s}^{-1}$ ). The corresponding figures in the forest site for 2011 was UV$\mathrm{B}=0.05 \pm 0.10 \mathrm{~W} \mathrm{~m}^{-2}$ (range: $0-0.70 \mathrm{~W} \mathrm{~m}^{-2}$ ) and wind speed $=0.5 \pm 0.4 \mathrm{~m} \mathrm{~s}^{-1}$ (range: $0.1-7.2 \mathrm{~m} \mathrm{~s}^{-1}$ ). These re- sults imply that, even though the two campaigns were conducted in different years, the meteorological conditions were comparable.

\subsection{Condensation sink (CS)}

The growth rate (GR) of nucleated particles is quantified by the gradient of Mode $\mathrm{D}_{p}$ against time during a NPF event:

$\mathrm{GR}=\frac{\Delta \operatorname{ModeD}_{p}}{\Delta t}$

where $\Delta t$ is the time period of the growth of freshly nucleated particles below $40 \mathrm{~nm}$.

The condensation sink (CS) value indicates how rapidly condensable vapors will condense on pre-existing particles and has units of $1 \mathrm{~s}^{-1}$. The CS can be calculated by integrating or summing over a particle size spectrum $\left[\mathrm{n}\left(\mathrm{D}_{p}\right)\right]$ as follows (Kulmala et al., 2001; Dal Maso et al., 2002):

$\mathrm{CS}=2 \pi D \int_{0}^{\infty} \mathrm{D}_{p} \beta_{M}\left(\mathrm{D}_{p}\right) n\left(\mathrm{D}_{p}\right) d \mathrm{D}_{p}=2 \pi D \sum_{i} \beta_{M} \mathrm{D}_{p i} N_{i}$

where $D$ is the diffusion coefficient and typically is taken as that for $\mathrm{H}_{2} \mathrm{SO}_{4}$ in air (Hanson and Eisele, 2000), $\beta_{M}$ is 
Table 2. Summary of new particle formation (NPF) events at the urban site during the summer of 2011.

\begin{tabular}{llllcc}
\hline Date & $\begin{array}{l}\text { Nucleation } \\
\text { burst start }\end{array}$ & $\begin{array}{l}\text { Mode } \mathrm{D}_{p}^{1} \\
(\mathrm{~nm})\end{array}$ & $\begin{array}{l}\text { Growth rate } \\
\left(\mathrm{nm} \mathrm{h}^{-1}\right)^{2}\end{array}$ & $\begin{array}{c}\text { Peak particle number concentration } \\
\left.\text { (particles cm }^{-3}\right)\end{array}$ \\
\cline { 5 - 6 } & & & & $N_{\text {nuc_urban }}^{4}$ & $N_{\text {Aitken }}^{5}$ \\
\hline 21 Jul 2011 & $8: 30-9: 00$ LT & 17 & 5.6 & 3800 & 5500 \\
24 Jul 2011 & $08: 00-08: 30$ LT & 19 & 5.5 & 5000 & 6600 \\
27 Jul 2011 & 10:00-10:30 LT & 24 & 7.2 & 7800 & 6300 \\
31 Jul 2011 & $9: 00-9: 30$ LT & 12 & N/A & 5200 & 1200 \\
1 Aug 2011 & 10:00-10:30 LT & 14 & 7.8 & 5500 & 6000 \\
2 Aug 2011 & $09: 30-10: 00$ LT & 15 & N/A & 5500 & 6700 \\
3 Aug 2011 & $09: 30-10: 00$ LT & 14 & N/A & 3500 & 3700 \\
5 Aug 2011 & $07: 00-07: 30$ LT & 13 & N/A & 12000 & 4500 \\
6 Aug 2011 & $09: 30-10: 00$ LT & 22 & 5.0 & 4800 & 5700 \\
8 Aug 2011 & $11: 00-11: 30$ LT & 18 & 6.6 & 4000 & 2100 \\
MIN & & 12 & 5.0 & 3500 & 6700 \\
MAX & & 24 & 7.8 & 12000 & 4800 \\
AVG & & 17 & 6.3 & 5700 & 1900 \\
S.D. & & 4 & 1.1 & 2600 & \\
\hline
\end{tabular}

${ }^{1}$ Mode $\mathrm{D}_{p}$ : peak diameter is obtained from a log-normal Gaussian fit of particle number size distribution smaller than $100 \mathrm{~nm}$.

${ }^{2}$ Growth rate is calculated by the gradient of Mode $\mathrm{D}_{p}$ against time during the period when particle growth was below $40 \mathrm{~nm}$.

${ }^{3}$ Peak particle number concentration is an average of the five highest measurements.

${ }^{4} N_{\text {nuc urban }}$ : particle number concentration between $7 \mathrm{~nm}$ and $30 \mathrm{~nm}$.

${ }^{5} N_{\text {Aitken }}$ : particle number concentration between $30 \mathrm{~nm}$ and $100 \mathrm{~nm}$.

the transitional regime correction factor, $\mathrm{D}_{p i}$ is the particle diameter of size class $i$, and $\mathrm{N}_{i}$ is the particle number concentration in size class $i$. The transitional correction factor $\left(\beta_{M}\right)$ can be expressed by the following formula (Fuchs and Sutugin, 1971):

$\beta_{M}=\frac{K_{n}+1}{0.377 K_{n}+1+\frac{4}{3} \alpha^{-1} K_{n}^{2}+\frac{4}{3} \alpha^{-1} K_{n}}$

where $\alpha$ is the mass accommodation coefficient ("sticking" coefficient) and is assumed to be unity, and $\mathrm{K}_{n}$ is Knudsen number and can be expressed in terms of particle diameter and the mean free path of vapor molecules, $\lambda$ as $\mathrm{K}_{n}=2 \lambda / \mathrm{D}_{p}$. Pressure and temperature dependent $\lambda$ values can be determined from the following formula (Willeke, 1976):

$\lambda=\lambda_{r}\left(\frac{101}{P}\right)\left(\frac{T}{293}\right)\left(\frac{1+110 / 293}{1+110 / T}\right)$

where $P$ is a pressure in $\mathrm{kPa}$ and $T$ is a temperature in $\mathrm{K} . \lambda_{r}$ is the mean free path under standard conditions $(293 \mathrm{~K}$ and 1 atmospheric pressure).

\section{Results and discussion}

\subsection{Overview of new particle formation (NPF) events at the urban and forest sites}

A NPF event is generally defined as a two-phase process involving the burst of nucleation mode particles and the growth of these particles into Aitken or accumulation mode by condensation and/or coagulation (Kulmala et al., 2004). Particles generated from the burst in the nucleation mode were denoted as nucleated particles in this study. Increases in the number concentrations of UFP can be attributed to either nucleation mode particles or Aitken mode particles. Because the size of nucleated particles formed via the gas to particle conversion process is generally smaller than $30 \mathrm{~nm}$ (Park et al., 2008; Watson et al., 2006), the ratio of the number concentrations of nucleation mode particles to those of UFP was used to distinguish NPF events from UFP burst events. Thus, a NPF event at each site was defined as a sharp increase in the $N_{\text {nuc }} / N_{\text {UFP }}$ ratios of $>0.5$ with elevated $N_{\text {UFP }}$, as shown in Fig. 3.

On the basis of these criteria, 10 NPF events were characterized at the urban site (Table 2), corresponding to $53 \%$ of the measurement days $(n=19)$, whereas seven NPF events were observed at the forest site (Table 3), corresponding to $47 \%$ of the measurement days $(n=15)$. The burst of nucleation mode particles at the urban site typically started in the morning (07:00-11:30 LT) (Table 2). However, the burst of nucleation mode particles at the forest site typically started around noon (10:30-14:30 LT) (Table 3). The time gap in the burst of nucleation mode particles between the two sites will be discussed in Sect. 3.4.

Average number size distributions of freshly nucleated particles at the two sites were obtained from data collected over a one hour period from the beginning of the burst of nucleation mode particles as shown in Fig. 4. Average number 
(a) Urban site

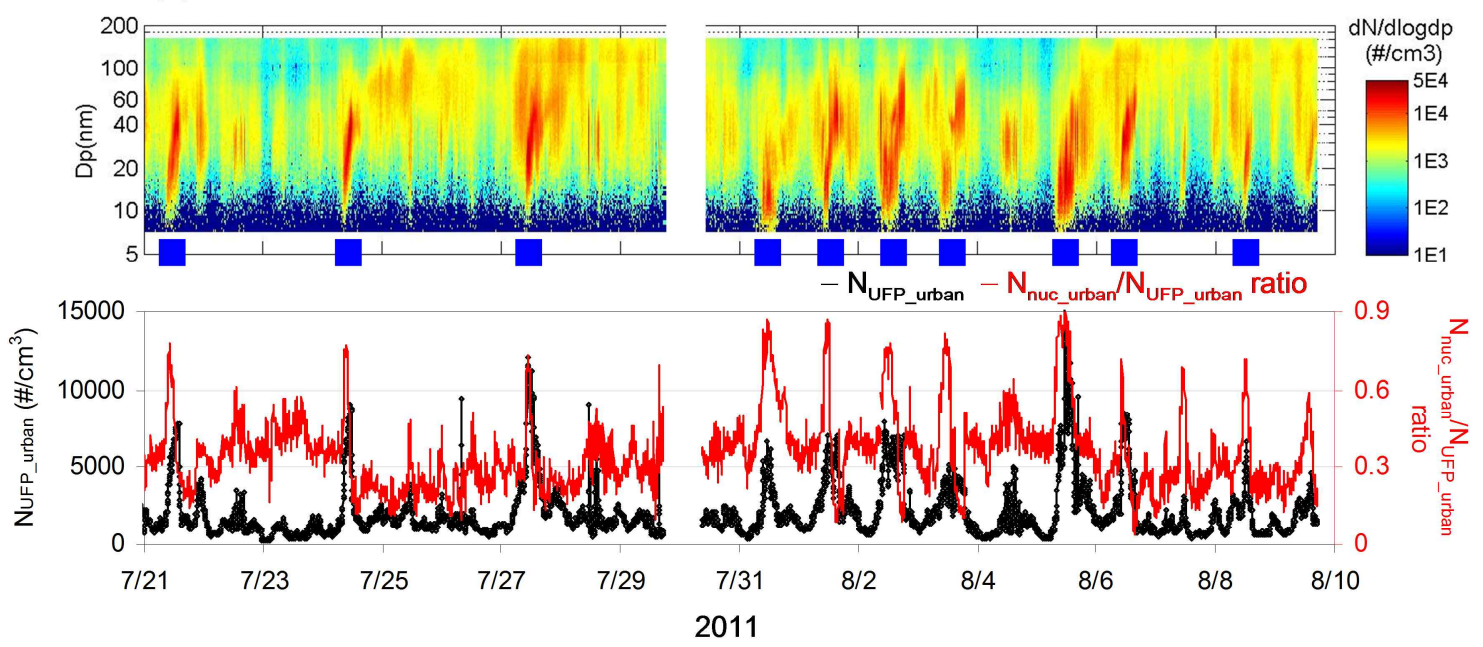

(b) Forest site

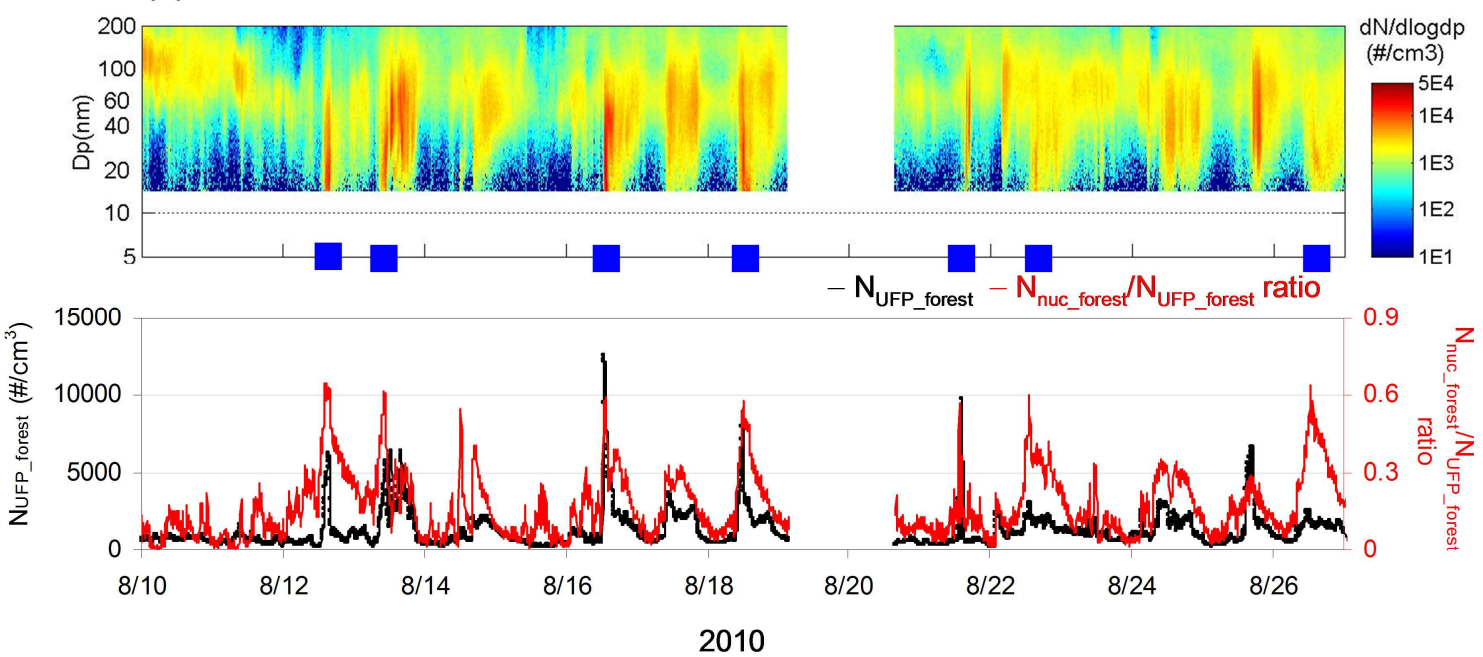

Fig. 3. Temporal evolutions of log-normal particle number size distributions, the number concentrations of the ultrafine particles and the ratios of the number concentrations of the nucleation mode particles to the ultrafine particles at (a) the urban and (b) forest sites. Blue filled rectangles represent new particle formation (NPF) events. The unit "\# $\mathrm{cm}^{-3}$ " represents particles per cubic centimeter. $N_{\text {nuc_urban }}$ and $N_{\text {UFP_urban }}$ at the urban site represent integrated number concentrations from $7 \mathrm{~nm}$ to $30 \mathrm{~nm}$ and from $7 \mathrm{~nm}$ to $100 \mathrm{~nm}$, respectively. $N_{\text {nuc_forest }}$ and $N_{\text {UFP_forest }}$ at the forest site represent integrated number concentrations from $14 \mathrm{~nm}$ to $30 \mathrm{~nm}$ and from $14 \mathrm{~nm}$ to $100 \mathrm{~nm}$, respectively.

size distributions of freshly nucleated particles at the urban site showed clear unimodal distributions with peaks centered at $10-30 \mathrm{~nm}$ (Fig. 4a). The number size distributions of freshly nucleated particles at the forest site also showed peaks centered at $10-30 \mathrm{~nm}$ but additional peaks were often observed in the Aitken mode (Fig. 4b), resulting in relatively broad particle number size distributions compared to the urban site. A Mode $\mathrm{D}_{p}$ of nucleated particles was obtained using a log-normal Gaussian fit of the number size distributions of freshly nucleated particles. The Mode $\mathrm{D}_{p}$ of freshly nucleated particles at the urban site ranged from $12 \mathrm{~nm}$ to $24 \mathrm{~nm}$ with an average of $17 \pm 4 \mathrm{~nm}$ (Fig. $4 \mathrm{c}$ and Table 2) whereas those at the forest site ranged from $16 \mathrm{~nm}$ to $25 \mathrm{~nm}$ with an average of $20 \pm 3 \mathrm{~nm}$ (Fig. $4 \mathrm{~d}$ and Table 3).

Jung and Kawamura (in preparation) measured sizesegregated hygroscopic growth factors at $85 \% \mathrm{RH}$ $[g(85 \%)]$, defined as the ratio of the particle diameter at $85 \% \mathrm{RH}$ to that under dry conditions, of particles at the urban site during the same measurement periods. They found that the $g(85 \%)$ of freshly nucleated particles at the urban site ranged from 1.11 to 1.22 with an average of $1.14 \pm 0.04$, which were similar to values of secondary organic aerosols (Virkkula et al., 1999; Saathoff et al., 2003; Sjogren et al., 2008). Their results suggest that nucleated particles 
(a)

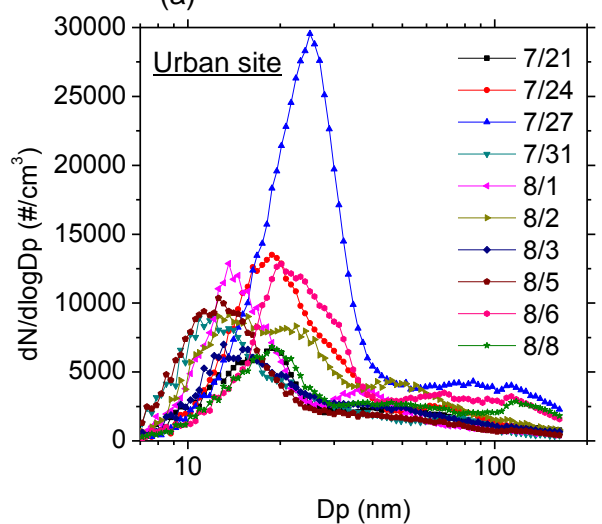

(c)

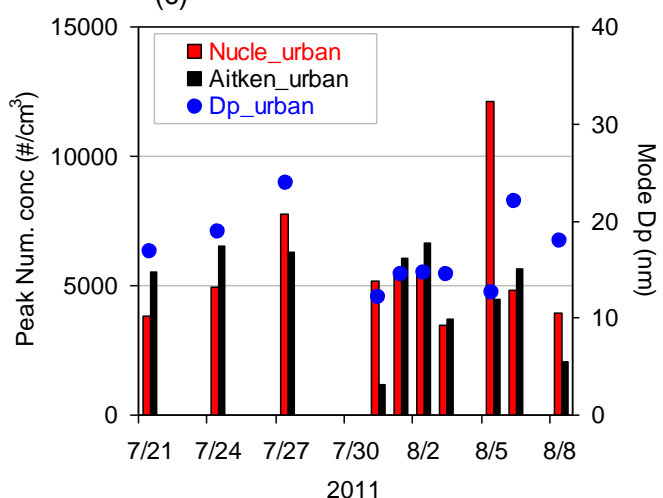

(b)

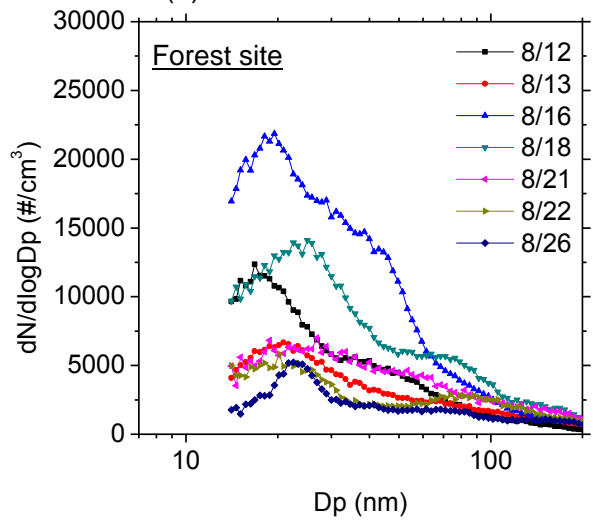

(d)

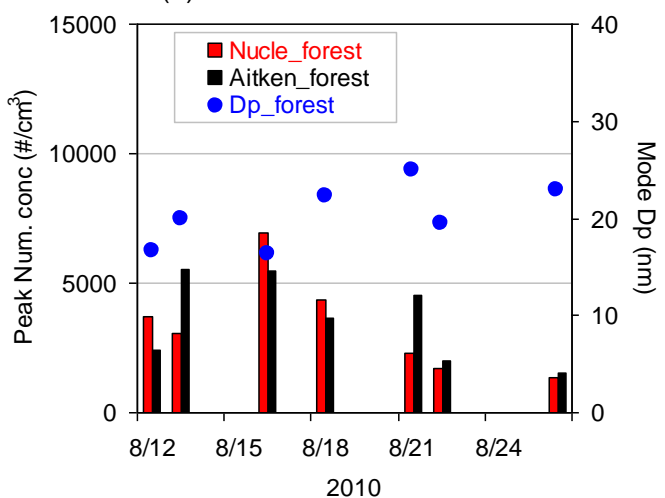

Fig. 4. Average number size distributions of freshly nucleated particles at (a) the urban and (b) forest sites during the periods with NPF events as well as maximum peak number concentrations of nucleation and Aitken size mode particles and mode peak diameter (Mode $\mathrm{D}_{p}$ ) during the periods with NPF events at (c) the urban and (d) forest sites. The nucleation size mode is defined as $7 \mathrm{~nm}<\mathrm{D}_{p}<30 \mathrm{~nm}$ and $14 \mathrm{~nm}$ $<\mathrm{D}_{p}<30 \mathrm{~nm}$ for the urban and forest sites, respectively, whereas the Aitken size mode is defined as $30 \mathrm{~nm}<\mathrm{D}_{p}<100 \mathrm{~nm}$ for both sites. Maximum peak particle number concentration was calculated from an average of the five highest measurements. Mode $\mathrm{D}_{p}$ was obtained from a log-normal Gaussian fit of the number size distribution of nucleated particles.

Table 3. Summary of NPF events at the forest site during the summer of 2010.

\begin{tabular}{lllcc}
\hline Date & Nucleation burst start & Mode $\mathrm{D}_{p}(\mathrm{~nm})$ & \multicolumn{2}{c}{$\begin{array}{c}\text { Peak particle number concentration } \\
\text { (particles } \mathrm{cm}^{-3} \text { ) }\end{array}$} \\
\cline { 3 - 5 } & & & $N_{\text {nuc_forest }}^{*}$ & $N_{\text {Aitken }}$ \\
\hline 12 Aug 2010 & $14: 00-14: 30$ LT & 17 & 3700 & 2400 \\
13 Aug 2010 & $10: 30-11: 00$ LT & 20 & 3100 & 5500 \\
16 Aug 2010 & $13: 00-13: 30$ LT & 16 & 6900 & 5500 \\
18 Aug 2010 & $11: 30-12: 00$ LT & 22 & 4300 & 3600 \\
21 Aug 2010 & $13: 30-14: 00$ LT & 25 & 2300 & 4600 \\
22 Aug 2010 & $13: 00-13: 30$ LT & 19 & 1700 & 2000 \\
26 Aug 2010 & $11: 30-12: 00$ LT & 23 & 1300 & 1500 \\
MIN & & 16 & 1300 & 1500 \\
MAX & & 25 & 6900 & 5500 \\
AVG & & 20 & 3300 & 3600 \\
S.D. & & 3 & 1900 & 1700 \\
\hline
\end{tabular}

$* N_{\text {nuc_forest }}:$ particle number concentration between $14 \mathrm{~nm}$ and $30 \mathrm{~nm}$. 
at the urban site were mainly produced via condensation of organic vapors into nuclei clusters (Jang and Kamens, 2001; Zhang and Wexler, 2002). Internal mixtures of sulfate with dominant fraction of organics are also possible at the urban site during the nucleation periods. The $g(85 \%)$ (1.11-1.22) of freshly nucleated particles can be explained by internal mixtures of non-hygroscopic organic compounds with highly hygroscopic ammonium sulfate having $g(85 \%)$ of 1.56 (Jung et al., 2010).

Peak number concentrations of nucleation and Aitken mode particles during the periods with NPF events at the two sites are summarized in Tables 2 and 3. Peak particle number concentration was obtained from the average of the highest five measurements during the periods with NPF events. Peak $N_{\text {nuc_urban }}$ at the urban site ranged from 3500 to 12000 particles $\mathrm{cm}^{-3}$ with an average of $5700 \pm 2600$ particles $\mathrm{cm}^{-3}$, whereas peak $N_{\text {Aitken }}$ ranged from 1200 to 6700 particles $\mathrm{cm}^{-3}$ with an average of $4800 \pm 1900$ particles $\mathrm{cm}^{-3}$ (Table 2 and Fig. 4c). Lower peak number concentrations obtained at the forest site; 1300 6900 particles $\mathrm{cm}^{-3} \quad$ (avg. $\quad 3300 \pm 1900$ particles $\mathrm{cm}^{-3}$ ) for $N_{\text {nuc_forest }}$ and $1500-5500$ particles $\mathrm{cm}^{-3}$ (avg. $3600 \pm 1700$ particles $\mathrm{cm}^{-3}$ ) for $N_{\text {Aitken }}$ (Table 3 and Fig. 4d). To compare the number concentrations of nucleation mode particles between the two sites, average number concentrations of particles from $14 \mathrm{~nm}$ to $30 \mathrm{~nm}$ at the urban site were also calculated to be $4500 \pm 2200$ particles $\mathrm{cm}^{-3}$ (range: $2300-9400$ particles $\mathrm{cm}^{-3}$ ). In summary, the number concentrations of nucleated particles at the urban site were higher than those at the forest site.

\subsection{Characteristics of NPF events at urban site}

Figure 5 shows diel variations in $N_{\text {nuc_urban }}, \mathrm{SO}_{2}, \mathrm{O}_{3}$, and the UV index at the urban site during NPF events. The bursts of nucleation mode particles were strongly correlated with increases in $\mathrm{SO}_{2}$ and $\mathrm{O}_{3}$ concentrations and the $\mathrm{UV}$ index in the morning. The burst of nucleation mode particles can occur by activation of the existing nuclei cluster pool (Kulmala et al., 2007) or by rapid formation of new nuclei clusters during activation (Lehtipalo et al., 2010). Activation usually occurs when the concentrations of condensable gases rapidly increase via photochemical process during the day (Bzdek and Johnston, 2010). Sulfuric acid produced from photo-oxidation of $\mathrm{SO}_{2}$ can act as nuclei (Jaecker-Voirol and Mirabel, 1989; Korhonen et al., 1999) and can also contribute to the initial growth of nuclei clusters by direct condensation into nuclei clusters (Yue et al., 2010) or by serving as a catalyst (Jang and Kamens, 2001). Increased $\mathrm{O}_{3}$ concentrations during the period of high UV index in morning are favorable for the production of condensable organic vapors via photooxidation of anthropogenic and biogenic VOC (Laaksonen et al., 2008). Thus, it is suggested that increases in $\mathrm{SO}_{2}$ and $\mathrm{O}_{3}$ concentrations with elevated UV irradiance are important (a)

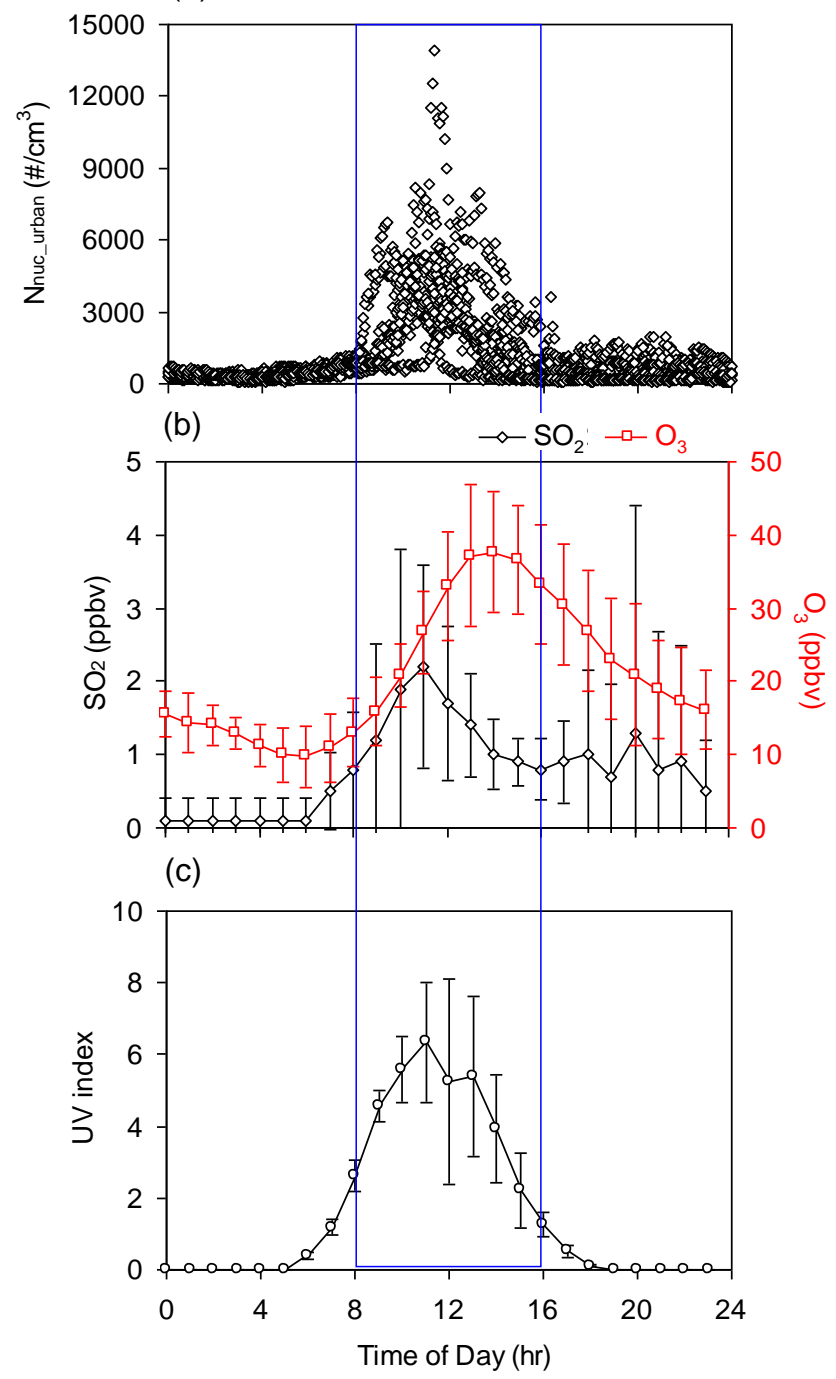

Fig. 5. Diel variations in (a) $N_{\text {nuc_urban, }}$ (b) $\mathrm{SO}_{2}, \mathrm{O}_{3}$ and (c) the UV index at the urban site during the periods with NPF events. The UV index was calculated using measured solar irradiance from $250 \mathrm{~nm}$ to $400 \mathrm{~nm}$ (UV-A and UV-B) and the erythema reference action spectrum. The UV index is a unitless quantity. The level of the UV index was defined as low $(<2)$, moderate (3-5), high (6-7), very high (8-10) and extreme $(>11)$.

for initiation of the burst of nucleation mode particles at the urban site.

Figure 6 shows temporal variations in $N_{\text {nuc_urban }}$, TSP, and $\mathrm{O}_{3}$ concentrations, and the UV index at the urban site for a selected day with non-NPF event (28-29 July 2011) and with NPF event (1-3 August 2011). During the periods with NPF events at the urban site on 1-3 August 2011, it was observed that $N_{\text {nuc_urban }}$ increased sharply as $\mathrm{O}_{3}$ concentrations increased under high UV index conditions (Fig. 6b). However, even though similar increases in ozone concentrations were observed under high UV index conditions on 28-29 
(a) non-NPF at the urban site
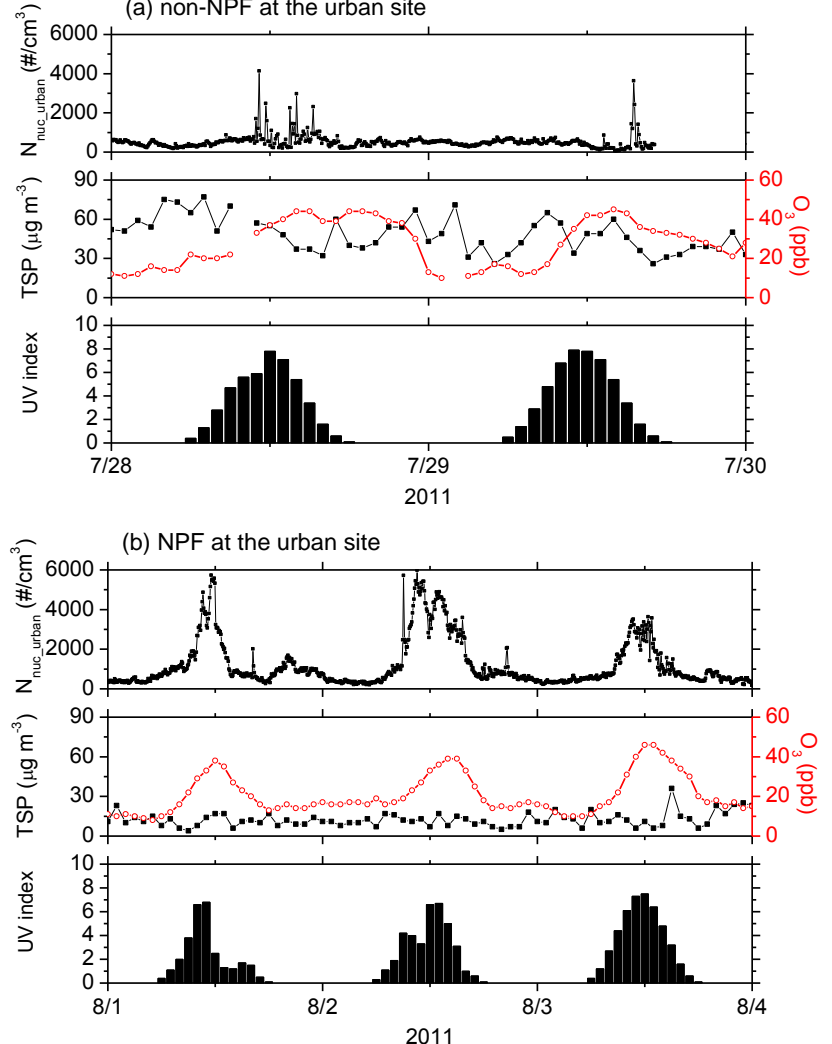

Fig. 6. $N_{\text {nuc_urban }}$, total suspended particle (TSP) mass concentration, ozone concentration, and UV index at the urban site during (a) 28-29 July and (b) 1-3 August 2011, corresponding to the periods with non-NPF events (non-NPF) and periods with NPF events, respectively.

July 2011, a burst of nucleation mode particles did not occur (Fig. 6a). A key distinction between the periods with NPF events and with non-NPF events in Fig. 6 is the difference in the mass concentrations of TSP. TSP mass concentrations (avg. $49 \pm 13 \mu \mathrm{g} \mathrm{m}^{-3}$ ) during the periods with nonNPF events were approximately four times higher than those (avg. $12 \pm 5 \mu \mathrm{g} \mathrm{m}^{-3}$ ) during the periods with NPF events (see Fig. 6).

Pre-existing particles can act as a sink for condensable organic or inorganic vapors of low volatility and for initially nucleated clusters of 1-2 nm particles, thus inhibiting a burst of nucleation mode particles (Kulmala, 2003). To examine the effect of the pre-existing particles on a nucleation burst event, the average CS between 06:00 and 07:00 LT was calculated for the selected days with non-NPF events (28-29 July 2011) and with NPF events (1-3 August 2011). Because the burst of nucleation mode particles at the urban site typically started after 07:00 LT (Table 2), particle number size distributions between 06:00 and 07:00 LT were selected to determine background conditions. Particle number size distributions from $5 \mathrm{~nm}$ to $1000 \mathrm{~nm}$ were reconstructed using a log-normal Gaussian fit of measured particle number size distributions and are shown in Fig. 7a, c as solid lines. The CS value was then calculated using Eq. (2) and is shown in Fig. $7 b$, d.

CS values $\left(0.051 \mathrm{~s}^{-1}\right.$ on 28 July 2011 and $0.014 \mathrm{~s}^{-1}$ on 29 July 2011) for the selected days with non-NPF events (Fig. 7b) were approximately two to five times higher than those $\left(0.0022-0.0037 \mathrm{~s}^{-1}\right)$ for the selected days with NPF events (Fig. 7d). CS values during the selected days with non-NPF events were similar to those $\left(0.0051-0.044 \mathrm{~s}^{-1}\right)$ obtained during the periods with NPF events at an urban site in Beijing, China, in the summer of 2006 (Yu et al., 2009). Very few NPF events (3-5 days in a month) occurred at the Beijing urban site during the summers of 2004, 2005, and 2006 due to the elevated CS level (Yu et al., 2009). The current results suggest that during the periods with non-NPF, abundant amounts of condensable vapors and initially nucleated clusters might be removed by the pre-existing particles due to a condensation sink at a heavily polluted urban site, thus inhibiting the burst of nucleation mode particles.

\subsection{Growth of nucleated particles at urban site}

Once formed, nuclei clusters grow to the size at which condensation of organics becomes possible via heterogeneous reactions, and then the particles further evolve to $\mathrm{CCN}$ via condensation of condensable vapors of low volatility (mainly organic vapors) (Jang and Kamens, 2001; Zhang and Wexler, 2002). Typical growth rates of nucleated particles range between $1-20 \mathrm{~nm} \mathrm{~h}^{-1}$ in the mid-latitudes (Kulmala et al., 2004). The growth rate of nucleated particles was calculated by the gradient of Mode $\mathrm{D}_{p}$ against time during the period when Mode $\mathrm{D}_{p}$ was below $40 \mathrm{~nm}$. The growth rates of nucleated particles at the urban site were calculated to be in the range of $5.0-7.8 \mathrm{~nm} \mathrm{~h}^{-1}$ with an average of $6.3 \pm 1.1 \mathrm{~nm} \mathrm{~h}^{-1}$ (Table 2), being similar to the values reported for other urban sites: i.e., East St. Louis, US (avg. $6.7 \pm 4.8 \mathrm{~nm} \mathrm{~h}^{-1}$ ) in summer (Qian et al., 2007), the Yangtze River delta, China $\left(6.4 \pm 1.6 \mathrm{~nm} \mathrm{~h}^{-1}\right.$, range: $\left.3.6-7.4 \mathrm{~nm} \mathrm{~h}^{-1}\right)$ in summer (Gao et al., 2009), and Brisbane, Australia $\left(4.6 \mathrm{~nm} \mathrm{~h}^{-1}\right.$, range: 1.79 $7.78 \mathrm{~nm} \mathrm{~h}^{-1}$ ) in spring-winter (Cheung et al., 2011).

Figure 8 shows diel variations in Mode $\mathrm{D}_{p}$ and wind direction at the urban site during the periods with NPF events. Interestingly, two different types of NPF events were observed with or without subsequent particle growth after the burst of nucleation mode particles. Nucleated particles on 21, 24, 27 July and 1, 6, 8 August 2011 (Case 1) gradually grew to particle diameters of approximately $40-50 \mathrm{~nm}$ or larger after the burst of nucleation mode particles (Fig. 8a). However, the subsequent growth of freshly nucleated particles did not occur on 31 July and 2, 3, 5 August 2011 (Case 2) (Fig. 8b). The NPF events were therefore categorized as a burst of nucleation mode particles with (Case 1) or without subsequent particle growth (Case 2). Cheung et al. (2011) also observed two different types of NPF events at an urban site in Brisbane, Australia. The burst of nucleation mode particles with 
Table 4. Summary of gas-phase pollutant concentrations and meteorological parameters at the urban site during the periods with NPF events for two different growth patterns.

\begin{tabular}{|c|c|c|c|}
\hline & & Case $1^{1}$ & Case $2^{2}$ \\
\hline \multirow{2}{*}{\multicolumn{2}{|c|}{$\begin{array}{l}\text { Date } \\
\text { Time }\end{array}$}} & 21, 24, $27 \mathrm{Jul}$ and 1, 6, 8 Aug 2011 & $31 \mathrm{Jul}$ and 2, 3, 5 Aug 2011 \\
\hline & & \multicolumn{2}{|c|}{ 08:00-16:00 LT } \\
\hline & & \multicolumn{2}{|c|}{$\mathrm{AVG} \pm$ S.D. $(\mathrm{MAX})$} \\
\hline $\mathrm{SO}_{2}$ & ppbv & $1.3 \pm 1.0(4)$ & $1.4 \pm 1.3(6)$ \\
\hline Non-methane hydrocarbon (NMHC) & ppmv & $0.09 \pm 0.07(0.52)$ & $0.06 \pm 0.01(0.09)$ \\
\hline $\mathrm{NO}_{2}$ & ppbv & $5.0 \pm 2.0(10)$ & $4.4 \pm 1.9(7)$ \\
\hline $\mathrm{O}_{3}$ & ppbv & $30 \pm 12(51)$ & $25 \pm 10(46)$ \\
\hline Wind direction ${ }^{3}$ & & $\mathrm{NW}>\mathrm{NE}>\mathrm{SE}$ & SE \\
\hline Wind speed & $\mathrm{ms}^{-1}$ & $2.8 \pm 1.2(6.1)$ & $3.4 \pm 1.9(7)$ \\
\hline Temperature & ${ }^{\circ} \mathrm{C}$ & $25 \pm 3.2(31)$ & $26 \pm 2.2(30)$ \\
\hline $\mathrm{RH}$ & $\%$ & $62 \pm 9(85)$ & $57 \pm 10(81)$ \\
\hline
\end{tabular}

${ }^{1}$ with or $^{2}$ without particle growth after the burst of nucleation mode particles.

${ }^{3} \mathrm{NW}$ : northwesterly wind, NE: northeasterly wind, SE: southeasterly wind.

(a)

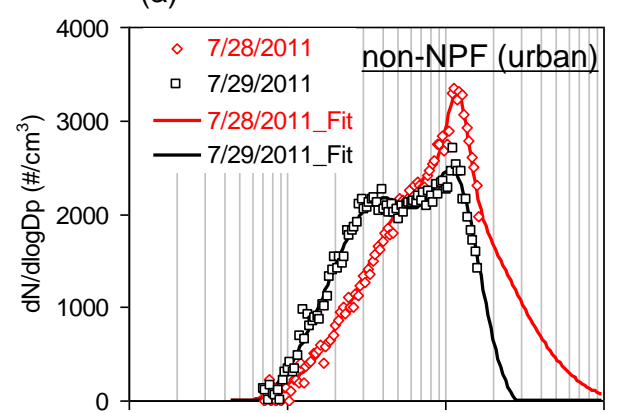

(c)

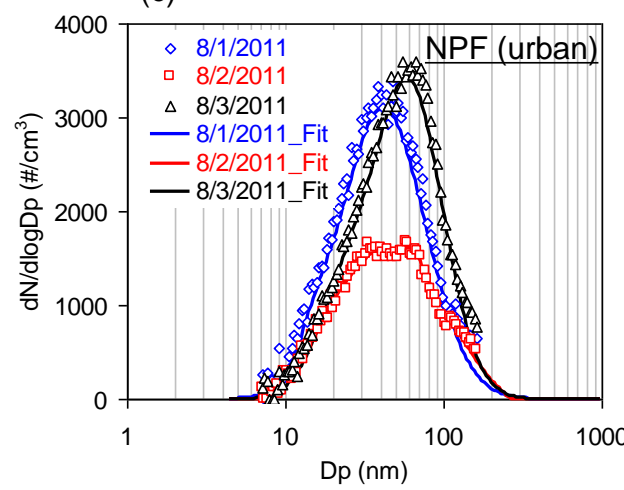

(b)

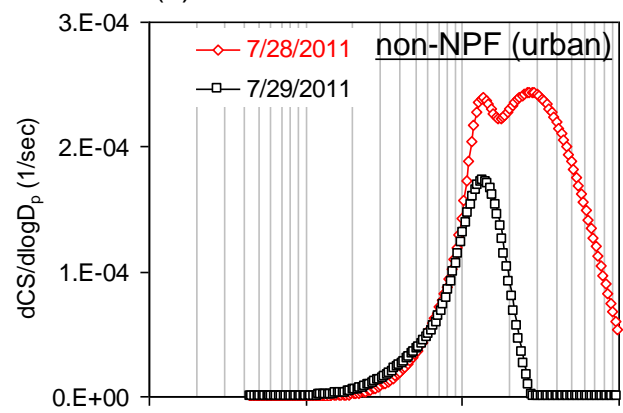

(d)

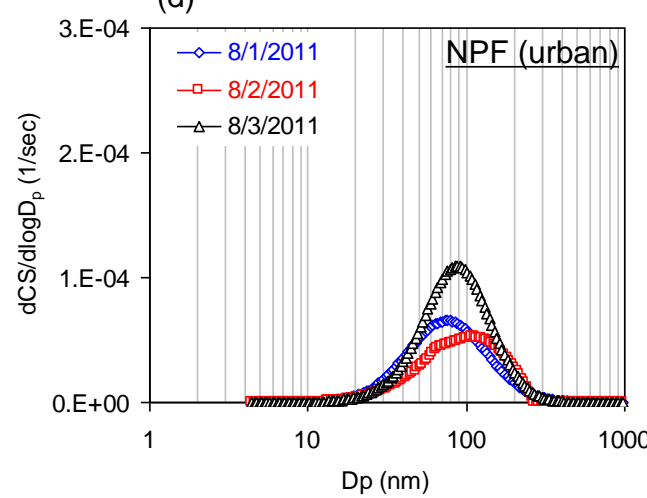

Fig. 7. (a, c) Average particle number size distributions and (b, d) their corresponding condensation sink (CS) averaged over 06:00-07:00 LT at the urban site on (a, b) 28-29 July 2011 during the periods with non-NPF events (non-NPF) and (c, d) 1-3 August 2011 during the periods with NPF events. Solid lines in (a) and (b) represent fitted log-normal Gaussian curves.

particle growth was found to be associated with particle precursors emitted from local traffic exhaust, whereas that without particle growth was associated with the transport of industrial emissions (Cheung et al., 2011).

Figure 9 present diel variations in $N_{\text {nuc_urban }}, N_{\text {Aitken }}$, $N_{\text {UFP_urban }}$ and Mode $\mathrm{D}_{p}$ at the urban site on 27 July and
5 August 2011 as typical examples for the Case 1 and Case 2 periods, respectively. It was observed that $N_{\text {Aitken }}$ on 27 July 2011 (Case 1) started to increase after the burst of nucleation mode particles (Fig. 9a). The increase in $N_{\text {Aitken }}$ was strongly correlated with the increase in Mode $\mathrm{D}_{p}$. However, $N_{\text {Aitken }}$ on 5 August 2011 (Case 2) was invariant for 
(a) $7 / 21,24,27,8 / 1,6,8,2011$

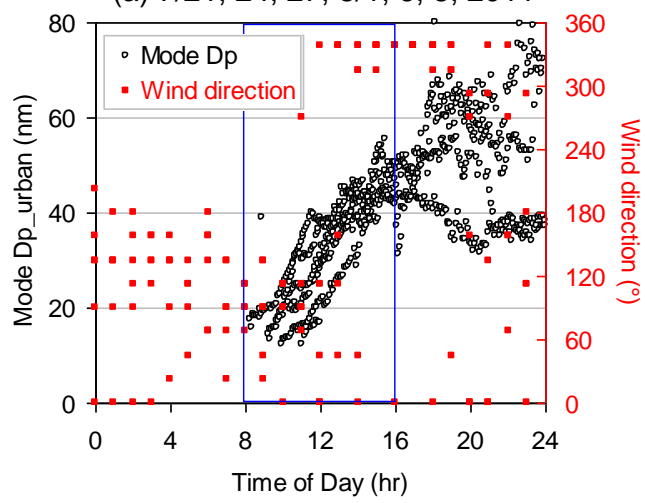

(b) $7 / 31,8 / 2,3,5,2011$

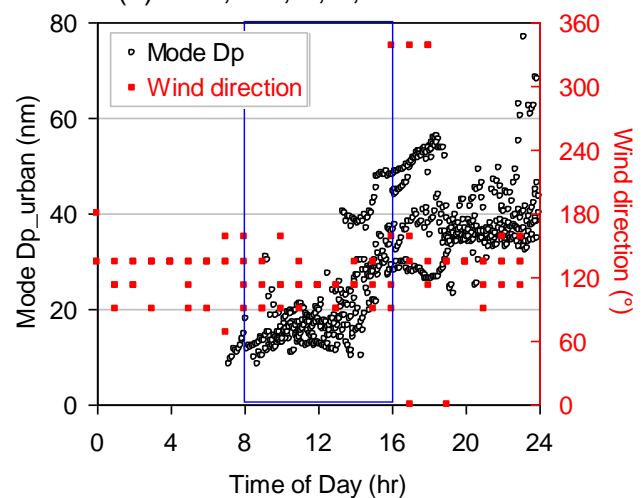

Fig. 8. Diel variations in Mode $D_{p}$ and wind direction at the urban site during the periods with NPF events on (a) 21, 24, 27 July and 1, 6, 8 August 2011 (Case 1) and (b) 31 July and 2, 3, 5 August 2011 (Case 2). The burst of nucleation mode particles and their subsequent growth usually occurred between 08:00 and 16:00 LT marked as empty blue rectangle.

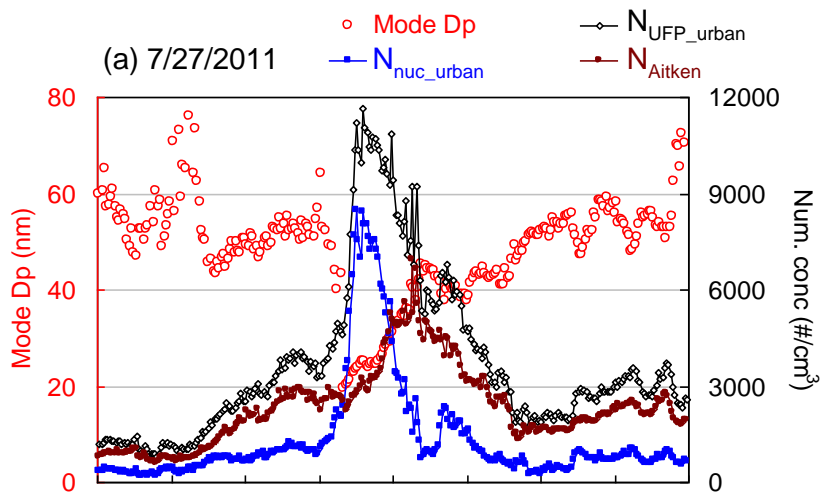

(b) $8 / 5 / 2011$

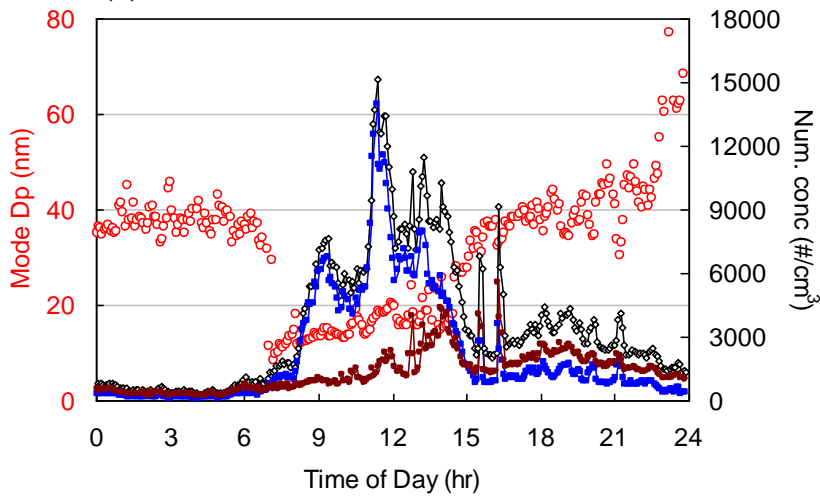

Fig. 9. Diel variations in Mode $\mathrm{D}_{p}, N_{\text {nuc_urban }}, N_{\text {Aitken, }}$, and $N_{\text {UFP_urban }}$ at the urban site during the periods with NPF events on (a) 27 July and (b) 2 August 2011 as typical examples of the Case 1 and Case 2 conditions, respectively.

more than 4-5 h after the burst of nucleation mode particles (Fig. 9b). The Mode $\mathrm{D}_{p}$ of nucleated particles also remained at a similar level below $20 \mathrm{~nm}$ for approximately $4-5$ hours. Several peaks of $N_{\text {nuc_urban }}$ were observed on 5 August 2011, indicating that the burst of nucleation mode particles continued to occur during the Case 2 period.

To better understand the two different NPF events at the urban site, several meteorological parameters and concentrations of gas-phase pollutants such as $\mathrm{SO}_{2}, \mathrm{NMHC}, \mathrm{NO}_{2}$ and $\mathrm{O}_{3}$ are shown in Table 4. Because the burst of nucleation mode particles and their subsequent growth usually occurred between 08:00 and 16:00 LT as seen in Fig. 8a, this time period was chosen to determine the relationship between levels of gaseous pollutants and the different particle growth patterns. It was observed that the growth pattern of nucleated particles could be classified on the basis of wind direction, as shown in Fig. 8. Southeasterly winds were predominant before the burst of nucleation mode particles. Interestingly, when wind direction shifted to northwesterly or northeasterly, nucleated particles started to grow after the burst of nucleation mode particles (Fig. 8a). However, if wind direction stayed southeasterly, nucleated particles did not grow for more than 4-5h (Fig. 8b). No significant differences in ambient temperature and $\mathrm{RH}$ were detected between the Case 1 and Case 2 periods (see Table 4).

Besides wind direction, relatively large differences in NMHC concentrations between the Case 1 and Case 2 periods were observed, with elevated concentrations during the Case 1 periods (Table 4). NMHC concentrations averaged over 08:00-16:00 LT during the Case 1 periods $(0.09 \pm 0.07 \mathrm{ppmv})$ were higher than those $(0.06 \pm 0.01$ ppmv) during the Case 2 periods (Table 4), indicating that concentrations of NMHC were enhanced during northwesterly or northeasterly winds (Case 1) compared to southeasterly winds (Case 2). Concentrations of $\mathrm{NO}_{2}$ and $\mathrm{O}_{3}$ during the Case 1 periods were slightly higher than those during the Case 2. However, $\mathrm{SO}_{2}$ concentrations averaged over 08:00-16:00 LT were similar between the Case 1 and Case 2 with average values of $1.3 \pm 1.0 \mathrm{ppbv}$ and $1.4 \pm 1.3 \mathrm{ppbv}$, respectively (Table 4), indicating that $\mathrm{SO}_{2}$ concentrations 


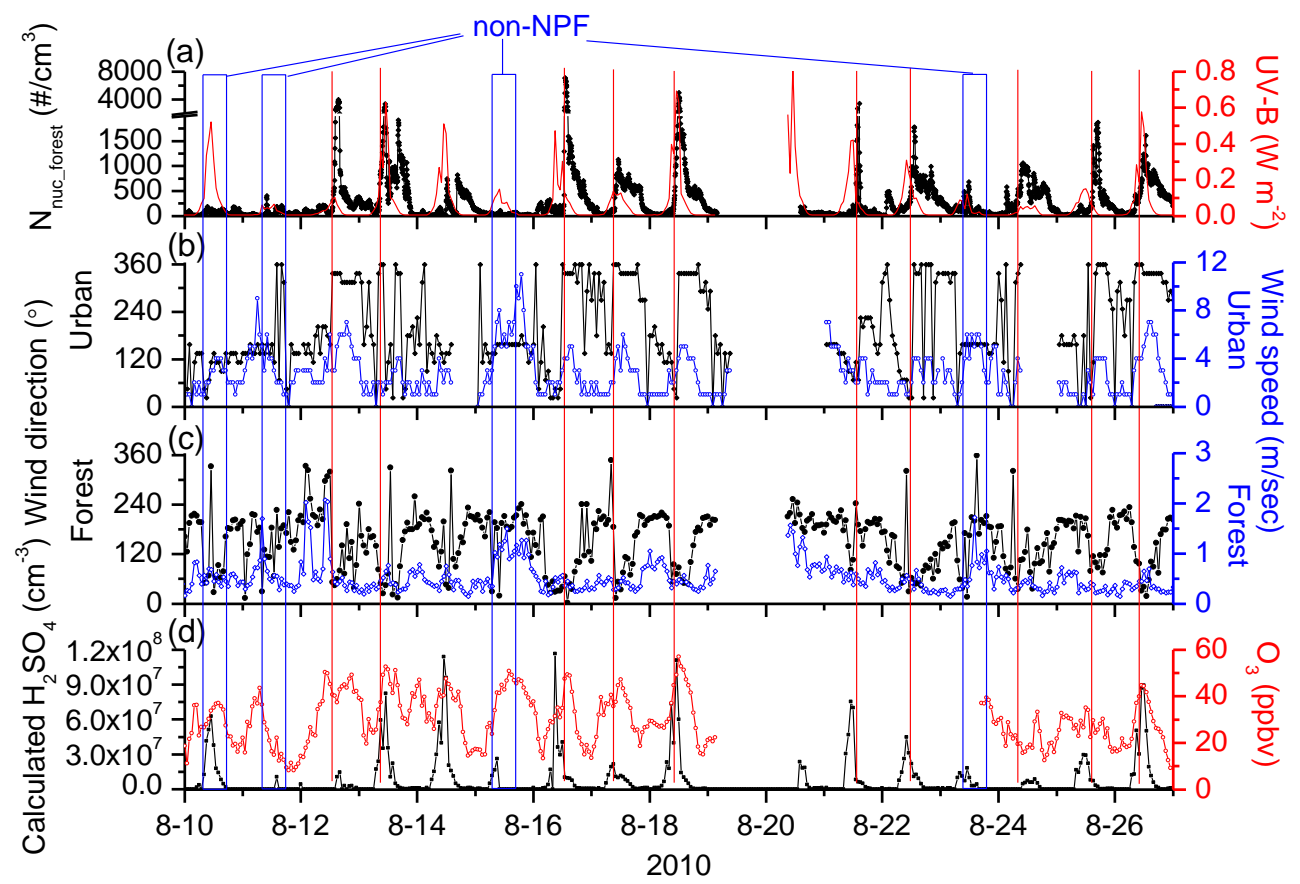

Fig. 10. Temporal variations in (a) $N_{\text {nuc_forest }}$ UV-B, (c) wind direction, wind speed, (d) calculated $\mathrm{H}_{2} \mathrm{SO}_{4}$, and $\mathrm{O}_{3}$ concentrations at the forest site during 10-26 August 2010. (b) Wind direction and wind speed measured at a meteorological observatory in urban Sapporo located $\sim 9.5 \mathrm{~km}$ north of the forest site are also shown. The $\mathrm{H}_{2} \mathrm{SO}_{4}$ concentration was calculated from $\mathrm{SO}_{2}$ data obtained from an urban observatory in Sapporo located $\sim 5 \mathrm{~km}$ north of the forest site based on Petäjä et al. (2009). Blue boxes and solid red lines represent the periods with non-NPF events (non-NPF) and with NPF events, respectively. Two different Y-axis scales are used for $N_{\text {nuc_forest }}: 500$ \# $\mathrm{cm}^{-3}$ increment for $0-2000 \# \mathrm{~cm}^{-3}$ and $2000 \# \mathrm{~cm}^{-3}$ increment for $2001-8000 \mathrm{~cm}^{-3}$.

were not substantially affected by a change in wind direction.

Because the growth of nucleated particles to $\mathrm{CCN}$ is thought to be mainly driven by condensation of low volatile organic vapors (Jang and Kamens, 2001; Zhang and Wexler, 2002), it is suggested that elevated concentrations of NMHC during northwesterly winds may accelerate the growth of nucleated particles at the urban site. The urban site was in the proximity of downtown Sapporo with the residential areas, including several public parks, to the north. Thus, it was suggested that emissions from the residential areas and public parks contained more NMHC than those from downtown Sapporo. However, the inflow of emissions from the downtown area did not accelerate the growth of nucleated particles but continued the burst of nucleation mode particles.

\subsection{Characteristics of NPF events at forest site}

The burst of nucleation mode particles at the forest site typically started around noon (10:30-14:30 LT) during the summer of 2010, which was delayed by approximately $3-4 \mathrm{~h}$ compared with the burst at the urban site during the summer of 2011. Figure 10 shows temporal variations in $N_{\text {nuc_forest }}$, UV-B intensity, wind direction, wind speed, and $\mathrm{O}_{3}$ concentration measured at the forest site during the entire measurement period. Wind direction and wind speed measured at a meteorological observatory in urban Sapporo, which is located at $\sim 9.5 \mathrm{~km}$ north of the forest site are shown in Fig. 10b. $\mathrm{H}_{2} \mathrm{SO}_{4}$ concentrations were calculated using the $\mathrm{SO}_{2}$ concentration, CS, and UV-B radiation data based on an equation for the proxy calculation given by Petäjä et al. (2009) (Fig. 10d). Increased $\mathrm{H}_{2} \mathrm{SO}_{4}$ concentrations were clearly observed during the NPF event periods at the forest site (Fig. 10d).

Elevated $N_{\text {nuc_forest }}$ values were observed at the forest site when the burst of nucleation mode particles occurred and are marked as vertical red lines. Interestingly, it was observed that the burst of nucleation mode particles at the forest was initiated when wind direction shifted to northeasterly (Fig. 10c). The shift of wind direction to northeasterly at the forest site during the periods with NPF events was consistent with the shift of wind direction to northwesterly at the meteorological observatory in urban Sapporo (Fig. 10b). A scatter plot of hourly average $N_{\text {nuc_forest }}$ versus local wind direction at the forest site is shown in Fig. 11, as a function of wind direction measured at the meteorological observatory in urban Sapporo presented as a colored bar. Increases in $N_{\text {nuc_forest }}$ were observed during northeasterly winds at the forest site and northwesterly winds at the meteorological observatory in urban Sapporo. These results imply that the inflow of air masses originating from urban Sapporo may play 


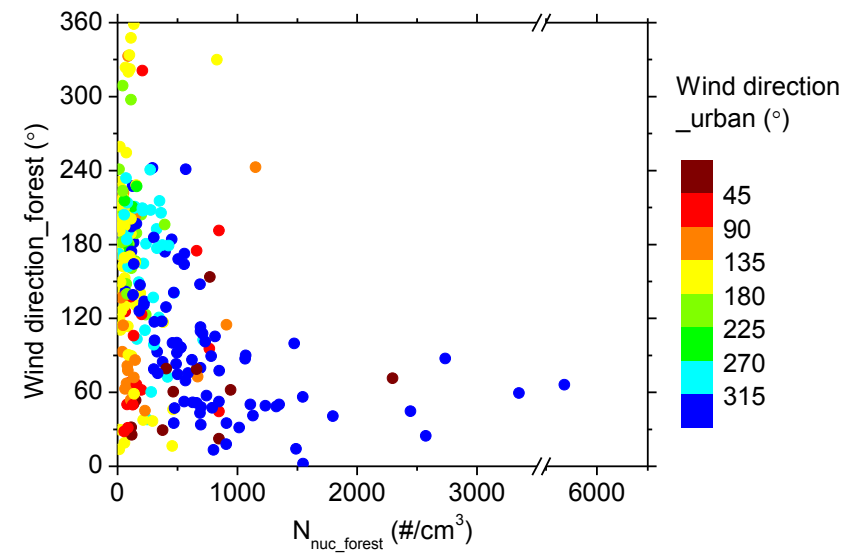

Fig. 11. Scatter plot of $N_{\text {nuc_forest }}$ versus local wind direction at the forest site as a function of wind direction measured at the meteorological observatory in urban Sapporo. The colored bar represents wind direction obtained at the meteorological observatory in urban Sapporo.

an important role in initiating the burst of nucleation mode particles at the forest site.

Because the SOA formation from biogenic precursors is accelerated in the presence of acid catalyst (e.g., Jang et al., 2002), the presence of acidic pollutants, such as sulfuric acid, is important in the formation of nuclei clusters and their initial growth to detectable size via heterogeneous condensation of organic vapors (Jang and Kamens, 2001; Zhang and Wexler, 2002; Kulmala, 2003). Increased $\mathrm{H}_{2} \mathrm{SO}_{4}$ concentrations at the nearby urban observatory, which is located at $\sim 5 \mathrm{~km}$ north of the forest site, were observed during the daytime (Fig. 10d). Thus, the inflow of anthropogenic pollutants from urban Sapporo may have been important in initiating the burst of nucleation particles at the forest site. Similarly, NPF events were always observed in the Colorado Rocky Mountains in the western United States when warm, polluted air masses arrived at a study site (Boy et al., 2008). Although there were few NPF events in a mixed deciduous forest in the northern United States, a NPF event was clearly observed during the inflow of a sulfur-rich plume (Kanawade et al., 2011).

The burst of nucleation mode particles did not occur on 10, 11, 15, and 23 August 2010 as marked in blue boxes (Fig. 10). During the periods with non-NPF events, wind directions were southerly to southwesterly at the forest site on 11, 15, and 23 August 2010 and southeasterly at the urban meteorological observatory on the same dates when UV-B intensity was low (Fig. 10a, c). These results imply that air masses originating from urban Sapporo rarely impacted the forest site during the periods with non-NPF events. Previous studies suggested that conventional NPF events do not occur in mixed deciduous forest, where emissions of biogenic isoprene are abundant (Kiendler-Scharr et al., 2009; Martin et al., 2010; Kanawade et al., 2011). One possible explanation for the non-NPF events is the inhibiting effect caused by isoprene that is emitted in the forest and can act as an $\mathrm{OH}$ scavenger (Kiendler-Scharr et al., 2009; Kanawade et al., 2011). Moreover, the decreased amount of $\mathrm{SO}_{2}$ transported from the urban area may result in the reduction of sulfuric acid leading to the suppression of NPF. Although the available data are limited to fully understand these effects, the current result suggests that the inflow of anthropogenic pollutants may be important in controlling NPF at the forest site.

However, many field and laboratory studies found that the SOA formation from isoprene was greatly enhanced in the presence of sulfuric acid through acid-catalyzed particle phase reactions (Jang et al., 2002; Edney et al., 2005; Surratt et al., 2007; Offenberg et al., 2009; Jaoui et al., 2010). Because the vegetation of the forest in this study is characterized by mixed deciduous trees (Miyazaki et al., 2012), the burst of nucleation mode particles at the forest site might result from photo-oxidation of locally emitted isoprene and its acid-catalyzed condensation reactions on nuclei clusters, under the inflow of anthropogenic pollutants from urban Sapporo.

This hypothesis is supported by measurements of the biogenic SOA tracers at the same deciduous forest in northern Japan during the summer (Miyazaki et al., 2012a, b). Miyazaki et al. (2012a) reported that isoprene SOA tracers such as 2-methyltetrols and $\mathrm{C}_{5}$-alkene triols at the same deciduous forest increased sharply during the summer and fall of 2010 (July-October). Fu and Kawamura (2011) reported that the isoprene SOA tracers showed clear diel variations with a continuous increase from early morning to late afternoon in the summer of 2001 at the Uryu forest site, which is located $\sim 200 \mathrm{~km}$ north of Sapporo and is characterized by a mixed deciduous forest.

To examine the effect of the pre-existing particles on nucleation burst at the forest site, the CS value averaged over 09:00-10:00 LT was calculated for selected days with nonNPF events (10, 11, 15, and 23 August 2010) (Fig. 12a) and with NPF events $(12,13,16,18,21,22$, and $26 \mathrm{Au}-$ gust 2010) (Fig. 12b). Because the burst of nucleation mode particles at the forest site generally started after 10:00 LT (Table 3), particle number size distributions between 09:00 and 10:00 LT were selected as a background condition. The CS value was calculated using particle number size distributions from $14 \mathrm{~nm}$ to $750 \mathrm{~nm}$ using Eq. (2). Average CS values $\left(0.0035-0.0063 \mathrm{~s}^{-1}\right)$ for the selected days with non-NPF events were similar to those $\left(0.0020-0.0057 \mathrm{~s}^{-1}\right)$ for the selected days with NPF events, as shown in Fig. 12c. These results suggest that a $\mathrm{CS}$ of condensable vapors on the preexisting particles was not important for the burst of nucleation mode particles at the forest site during the summer of 2010.

The growth rate of nucleated particles at the forest site was not clearly characterized. As shown in Fig. 3b, the burst of nucleation mode particles and the subsequent growth of these particles occurred almost simultaneously within one hour. 
(a)

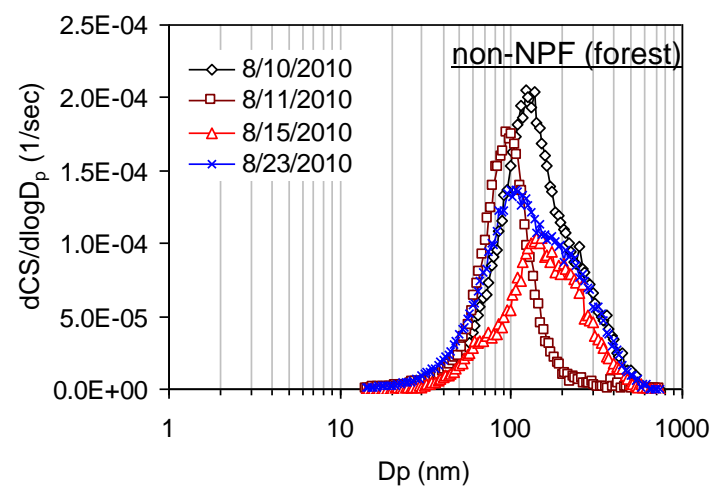

(b)

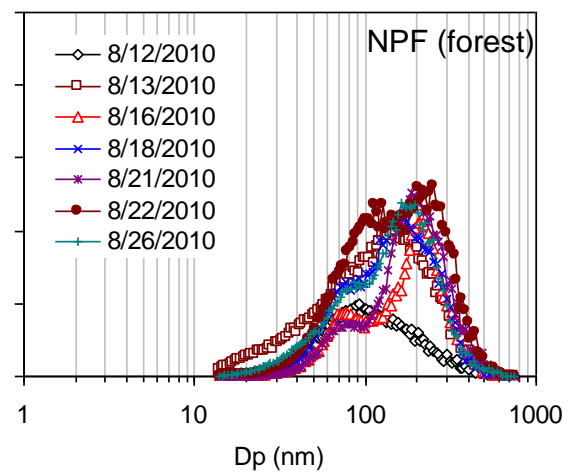

(c) Total CS anon-NPFםNPF

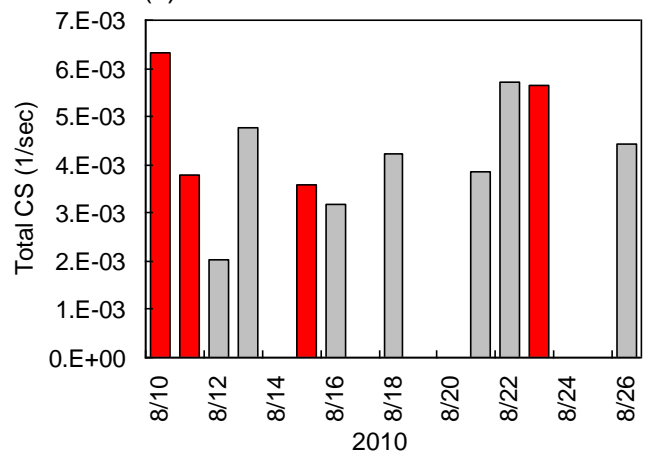

Fig. 12. CS values averaged over 09:00-10:00 LT at the forest site on (a) 10,11, 15, and 23 August 2010 during the periods with non-NPF events (non-NPF) and (b) 12, 13, 16, 18, 21, 22, and 26 August 2010 during the periods with NPF events. (c) Temporal variation in total CS is also shown.

This unique growth pattern, which cannot be well interpreted at present, needs further study with comprehensive measurement of the chemical composition of gaseous and particulate pollutants at the forest site.

\section{Summary and conclusions}

The burst of nucleation mode particles at the urban site during the summer of 2011 typically started in the morning (07:00-11:30 LT) with peak $N_{\text {nuc_urban }}$ values ranging from 3500 to 12000 particles $\mathrm{cm}^{-3}$. In total, $10 \mathrm{NPF}$ events were observed at the urban site, corresponding to $53 \%$ of the measurement days $(n=19)$. Mode $\mathrm{D}_{p}$ of nucleated particles at the urban site was obtained as $17 \pm 4 \mathrm{~nm}$ during the periods with NPF events. Diel variations in gas-phase pollutants and meteorological parameters suggest that increases in $\mathrm{SO}_{2}$ and $\mathrm{O}_{3}$ concentrations and the UV index in the morning under clear (sunny) conditions are needed for the burst of nucleation mode particles at the urban site. However, elevated concentrations of the pre-existing particles at the urban site inhibited the burst of nucleation mode particles due to a condensation sink (CS) of condensable vapors and initially nucleated clusters into the pre-existing particles.
NPF events at the urban site were classified into two groups of those with and without subsequent particle growth after the burst of nucleation mode particles. The growth rates of nucleated particles at the urban site ranged from 5.0 to $7.8 \mathrm{~nm} \mathrm{~h}^{-1}$ with an average of $6.3 \pm 1.1 \mathrm{~nm} \mathrm{~h}^{-1}$. Freshly nucleated particles started to grow after the burst of nucleation mode particles when wind direction shifted from southeasterly (from the downtown area) to northwesterly (from residential areas and public parks). However, if wind direction stayed as southeasterly, the subsequent growth of freshly nucleated particles did not occur. During the periods with NPF events, elevated concentrations of non-methane hydrocarbon (NMHC) were recorded when northwesterly winds dominated. These results suggest that the increase in NMHC concentrations may play an important role in the subsequent growth of freshly nucleated particles at the urban site.

The burst of nucleation mode particles at the forest site during the summer of 2010 delayed by 3-4 hours compared with that at the urban site during the summer of 2011. The burst of nucleation mode particles at the forest site typically started around noon (10:30-14:30 LT) with $N_{\text {nuc forest }}$ ranging from 1300 to 6900 particles $\mathrm{cm}^{-3}$. In total, seven NPF events were observed at the forest site, corresponding to $47 \%$ of the measurement days $(n=15)$. Mode $\mathrm{D}_{p}$ of freshly 
nucleated particles at the forest site was $20 \pm 3 \mathrm{~nm}$ during the periods with NPF events, which was similar to the value at the urban site. The burst of nucleation mode particles at the forest site usually started when wind direction shifted to northeasterly winds. These results imply that the inflow of air masses originating from urban Sapporo acted as a trigger for the initiation of the burst of nucleation mode particles in the deciduous forest, where isoprene emissions were abundant. Similar CS values were obtained during both periods with and without NPF events, suggesting that any condensation sink of condensable vapors on the pre-existing particles did not significantly affect the burst of nucleation mode particles at the forest site during the summer of 2010.

The present study suggested that the interaction between biogenic and anthropogenic emissions may be a very important factor in NPF in a deciduous forest. However, very few studies have been undertaken to investigate the interaction of biogenic and anthropogenic emissions in regard to NPF events in the ambient atmosphere. More studies including comprehensive measurements of the chemical and physical properties of gaseous and particulate components during NPF events are needed, particularly in deciduous forest sites adjacent to urban areas, in order to better understand the interaction between biogenic and anthropogenic emissions and its effect on NPF.

Acknowledgements. This work was supported by a Grant-in-Aid No. 2100923509 from the Japan Society for the Promotion of Science (JSPS) and by the Environment Research and Technology Development Fund (B-0903) of the Ministry of the Environment, Japan. We appreciate the financial support of a JSPS Fellowship to J. S. Jung. We acknowledge the support of K. Yamanoi of Hokkaido Research Center, Forestry and Forest Products Research Institute, Sapporo, Japan.

Edited by: T. Petäjä

\section{References}

Aggarwal, S. G. and Kawamura, K.: Carbonaceous and inorganic composition in long-range transported aerosols over northern Japan: Implication for aging of water-soluble organic fraction, Atmos. Environ., 43, 2532-2540, 2009.

Agarwal, S., Aggarwal, S. G., Okuzawa, K., and Kawamura, K.: Size distributions of dicarboxylic acids, ketoacids, $\alpha$ dicarbonyls, sugars, WSOC, OC, EC and inorganic ions in atmospheric particles over Northern Japan: implication for long-range transport of Siberian biomass burning and East Asian polluted aerosols, Atmos. Chem. Phys., 10, 5839-5858, doi:10.5194/acp10-5839-2010, 2010.

Birmili, W. and Wiedensohler, A.: New particle formation in the continental boundary layer: Meteorological and gas phase parameter influence, Geophys. Res. Lett., 27, 3325-3328, 2000.

Boulon, J., Sellegri, K., Venzac, H., Picard, D., Weingartner, E., Wehrle, G., Collaud Coen, M., Bütikofer, R., Flückiger, E., Baltensperger, U., and Laj, P.: New particle formation and ultrafine aerosol climatology at a high altitude site in the Alps (Jungfraujoch, 3580m a.s.1., Switzerland), Atmos. Chem. Phys., 10, 93339349, 2010, http://www.atmos-chem-phys.net/10/9333/2010/.

Boulon, J., Sellegri, K., Hervo, M., Picard, D., Pichon, J.-M., Fréville, P., and Laj, P.: Investigation of nucleation events vertical extent: a long term study at two different altitude sites, Atmos. Chem. Phys., 11, 5625-5639, doi:10.5194/acp-11-56252011, 2011.

Boy, M., Kazil, J., Lovejoy, E. R., Guenther, A., and Kulmala, M.: Relevance of ion-induced nucleation of sulfuric acid and water in the lower troposphere over the boreal forest at northern latitudes, Atmos. Res., 90, 151-158, 2008.

Bzdek, B. R. and Johnston, M. V.: New particle formation and growth in the troposphere, Anal. Chem., 82, 7871-7878, 2010.

Cheung, H. C., Morawska, L., and Ristovski, Z. D.: Observation of new particle formation in subtropical urban Environment, Atmos. Chem. Phys., 11, 3823-3833, doi:10.5194/acp-11-38232011, 2011.

Dal Maso, M., Kulmala, M., Lehtinen, K. E. J., Mäkelä, J. M., Aalto, P., and O'Dowd, C. D.: Condensation and coagulation sinks and formation of nucleation mode particles in coastal and boreal forest boundary layers, J. Geophys. Res., 107, 8097, doi:10.1029/2001JD001053, 2002.

Dunn, M. J., Jiménez, J.-L., Baumgardner, D., Castro, T., McMurry, P. H., and Smith, J. N.: Measurements of Mexico City nanoparticle size distributions: Observations of new particle formation and growth, Geophys. Res. Lett., 31, L10102, dio:10.1029/2004GL019482, 2004.

Edney, E. O., Kleindienst, T. E., Jaoui, M., Lewandowski, M., Offenberg, J. H.,Wang,W., and Claeys, M.: Formation of 2-methyl tetrols and 2-methylglyceric acid in secondary organic aerosol from laboratory irradiated isoprene/ $\mathrm{NO}_{x} / \mathrm{SO}_{2} /$ air mixtures and their detection in ambient $\mathrm{PM}_{2.5}$ samples collected in the eastern United States, Atmos. Environ., 39, 5281-5289, 2005.

Froyd, K. D., Murphy, S. M., Murphy, D. M., de Gouw, J. A., Eddingsaas, N. C., and Wennberg, P. O.: Contribution of isoprenederived organosulfates to free tropospheric aerosol mass, Proc. Natl. Acad. Sci., USA, 107, 21360-21365, 2010.

$\mathrm{Fu}$, P. and Kawamura, K.: Diurnal variations of polar organic tracers in summer forest aerosols: A case study of a Quercus and Picea mixed forest in Hokkaido, Japan, Geochem. J., 45, 297308, 2011.

Fuchs, N. A. and Sutugin, A. G.: Highly dispersed aerosol, in: Topics in Current Aerosol Research, edited by: Hidy, G. M. and Brock, J. R., Pergamon, New York, USA, 1-60, 1971.

Gao, J., Wang, T., Zhou, X., Wu, W., and Wang, W.: Measurement of aerosol number size distributions in the Yangtze River delta in China: Formation and growth of particles under polluted conditions, Atmos. Environ., 43, 829-836, 2009.

Hallar, A. G., Lowenthal, D. H., Chirokova, G., Borys, R. D., and Wiedinmyer, C.: Persistent daily new particle formation at a mountain-top location, Atmos. Environ., 45, 4111-4115, 2011.

Hamed, A., Korhonen, H., Sihto, S.-L., Joutsensaari, J., Järvinen, H., Petäjä, T., Arnold, F. Nieminen, T., Kulmala, M., Smith, J. N., Lehtinen, K. E. J., and Laaksonen, A.: The role of relative humidity in continental new particle formation, J. Geophys. Res., 116, D03202, doi:10.1029/2010JD014186, 2011. 
Hanson, D. R. and Eisele, F.: Diffusion of $\mathrm{H}_{2} \mathrm{SO}_{4}$ in humidified nitrogen: Hydrated $\mathrm{H}_{2} \mathrm{SO}_{4}$, J. Phys. Chem. A., 104, 1715-1719, 2000.

Held, A., Nowak, A., Birmili,W., Wiedensohler, A., Forkel, R., and Klemm, O.: Observations of particle formation and growth in a mountainous forest region in central europe, J. Geophys. Res., 109, D23204, doi:10.1029/2004JD005346, 2004.

Holmes, N. S.: A review of particle formation events and growth in the atmosphere in the various environments and discussion of mechanistic implications, Atmos. Environ., 41, 2183-2201, 2007.

Hoyle, C. R., Boy, M., Donahue, N. M., Fry, J. L., Glasius, M., Guenther, A., Hallar, A. G., Huff Hartz, K., Petters, M. D., Petäjä, T., Rosenoern, T., and Sullivan, A. P.: A review of the anthropogenic influence on biogenic secondary organic aerosol, Atmos. Chem. Phys., 11, 321-343, doi:10.5194/acp-11-321-2011, 2011.

Jaecker-Voirol, A. and Mirabel, P.: Heteromolecular nucleation in the sulfuric acid-water system, Atmos. Environ., 23, 2053-2057, 1989.

Jang, M. and Kamens, R. M.: Atmospheric secondary aerosol formation by heterogeneous reactions of aldehydes in the presence of a sulfuric acid aerosol catalyst, Environ. Sci. Technol., 35, 4758-4766, 2001.

Jang, M. S., Czoschke, N. M., Lee, S., and Kamens, R. M.: Heterogeneous atmospheric aerosol production by acid-catalyzed particle-phase reactions, Science, 298, 814-817, 2002.

Jaoui, M., Corse, E. W., Lewandowski, M., Offenberg, J. H., Kleindienst, T. E., and Edney, E. O.: Formation of organic tracers for isoprene SOA under acidic conditions, Atmos. Environ., 44, 1798-1805, 2010.

Jung, J., Kim, Y. J., Aggarwal, S. G., and Kawamura, K.: Hygroscopic property of water-soluble organic-enriched aerosols in Ulaanbaatar, Mongolia during the cold winter of 2007, Atmos. Environ., 45, 2722-2729, 2011.

Kanawade, V. P., Jobson, B. T., Guenther, A. B., Erupe, M. E., Pressley, S. N., Tripathi, S. N., and Lee, S.-H.: Isoprene suppression of new particle formation in a mixed deciduous forest, Atmos. Chem. Phys., 11, 6013-6027, doi:10.5194/acp-11-60132011, 2011.

Kiendler-Scharr, A., Wildt, J., Dal Maso, M., Hohaus, T., Kleist, E., Mentel, T. F., Tillmannn, R., Uerlings, R., Schurr, U., and Wahner, A.: New particle formation in forests inhibited by isoprene emissions, Nature, 461, 381-384, 2009.

Kitamori, Y., Mochida, M., and Kawamura, K.: Assessment of the aerosol water content in urban atmospheric particles by the hygroscopic growth measurements in Sapporo, Japan, Atmos. Environ., 43, 3416-3423, 2009.

Korhonen, P., Kulmala, M., Laaksonen, A., Viisanen, Y., McGraw, R., and Seinfeld, J. H.: Ternary nucleation of $\mathrm{H}_{2} \mathrm{SO}_{4}, \mathrm{NH}_{3}$, and $\mathrm{H}_{2} \mathrm{O}$ in the atmosphere, J. Geophys. Res., 104, 26349-26353, 1999.

Kulmala, M.: How particles nucleate and grow, Science, 302, 1000-1001, 2003.

Kulmala, M., Dal Maso, M., Mäkelä, J. M., Pirjola, L., Väkevä, M., Aalto, P., Miikkulainen, P., Hämeri, K., and O'Dowd, C.: On the formation, growth and composition of nucleation mode particles, Tellus B, 53, 479-490, 2001.

Kulmala, M., Vehkamäki, H., Petäjä, Dal Maso, T. M., Lauri, A., Kerminen, V.-M., Birmili, W. and McMurry, P. H.: Formation and growth rates of ultrafine atmospheric particles: a review of observations, J. Aerosol Sci., 35, 143-176, 2004.

Kulmala, M., Riipinen, I., Sipilä, M., Manninen, H. E., Petäjä, T., Junninen, H., Dal Maso, M., Mordas, G., Mirme, A., Vana, M., Hirsikko, A., Laakso, L., Harrison, R. M., Hanson, I., Leung, C., Lehtinen, K. E. J., and Kerminen, V. M.: Toward direct measurement of atmospheric nucleation, Science, 318, 82-92, 2007.

Laaksonen, A., Kulmala, M., O’Dowd, C. D., Joutesensaari, J., Vaattovaara, P., Mikkonen, S., Lehtinen, K. E. J., Sogacheva, L., Dal Maso, M., Aalto, P., Petäjä, T., Sogachev, A., Yoon, Y. J., Lihavainen, H., Nilsson, D., Facchini, M. C., Cavalli, F., Fuzzi, S., Hoffmann, T., Arnold, F., Hanke, M., Sellegri, K., Umann, B., Junkermann, W., Coe, H., Allan, J. D., Alfarra, M. R., Worsnop, D. R., Riekkola, M. L., Hyötyläinen, T., and Viisanen, Y.: The role of VOC oxidation products in continental new particle Formation, Atmos. Chem. Phys., 8, 2657-2665, doi:10.5194/acp-82657-2008, 2008.

Lehtipalo, K., Kulmala, M., Sipilä, M., Petäjä, T., Vana, M., Ceburnis, D., Dupuy, R., and O'Dowd C.: Nanoparticles in boreal forest and coastal environment: a comparison of observations and implications of the nucleation mechanism, Atmos. Chem. Phys., 10, 7009-7016, doi:10.5194/acp-10-7009-2010, 2010.

Martin, S. T., Andreae, M. O., Artaxo, P., Baumgardner, D., Chen, Q., Goldstein, A. H., Guenther, A., Heald, C. L., Mayol-Bracero, O. L., McMurry, P. H., Pauliquevis, T., Pöschl, U., Prather, K. A., Roberts, G. C., Saleska, S. R., Silva Dias, M. A., Spracklen, D. V., Swietlicki, E., and Trebs, I.: Sources and properties of Amazonian aerosol particles, Rev. Geophys., 48, RG2002, doi:10.1029/2008RG000280, 2010.

Metzger, A., Verheggen, B., Dommen, J., Duplissy, J., Prevot, A. S., Weingartner, E., Riipinen, I., Kulmala, M., Spracklen, D. V., Carslaw, K. S., and Baltensperger, U.: Evidence for the role of organics in aerosol particle formation under atmospheric conditions, P. Natl. Acad. Sci. USA, 107, 6646-6651, 2010.

Mikkonen, S., Lehtinen, K. E. J., Hamed, A., Joutsensaari, J., Facchini, M. C., and Laaksonen, A.: Using discriminant analysis as a nucleation event classification method, Atmos. Chem. Phys., 6, 5549-5557, doi:10.5194/acp-6-5549-2006, 2006.

Miyazaki, Y., Fu, P., Kawamura, K., Mizoguchi, Y., and Yamanoi, $\mathrm{K}$. : Seasonal variations of stable carbon isotopic composition and biogenic tracer compounds of water-soluble organic aerosols in a deciduous forest, Atmos. Chem. Phys., 12, 1367-1376, doi:10.5194/acp-12-1367-2012, 2012a.

Miyazaki, Y., Jung, J., Fu, P., Mizoguchi, Y., Yamanoi, K., and Kawamura, K.: Evidence of formation of submicrometer water-soluble organic aerosols at a deciduous forest site in northern Japan in summer, J. Geophys. Res., 117, D19213, doi:10.1029/2012JD018250, 2012b.

Neitola, K., Asmi, E., Komppula, M., Hyvärinen, A.-P., Raatikainen, T., Panwar, T. S., Sharma, V. P., and Lihavainen, H.: New particle formation infrequently observed in Himalayan foothills-why?, Atmos. Chem. Phys., 11, 8447-8458, doi:10.5194/acp-11-8447-2011, 2011.

Nishita, C., Osada, K., Kido, M., Matsunaga, K., and Iwasaka, Y.: Nucleation mode particles in upslope valley winds at Mount Norikura, Japan: Implications for the vertical extent of new particle formation events in the lower troposphere, J. Geophys. Res., 113, D06202, doi:10.1029/2007JD009302, 2008. 
O'Dowd, C. D., Aalto, P., Hameri, K., Kulmala, M., and Hoffmann, T.: Atmospheric particles from organic vapours, Nature, 416, 497-498, 2002.

Offenberg, J. H., Lewandowski, M., Edney, E. O., Kleindienst, T. E., and Jaoui, M.: Influence of aerosol acidity on the formation of secondary organic aerosol from biogenic precursor hydrocarbons, Environ. Sci. Technol., 43, 7742-7747, 2009.

Ortega, J., Helmig, D., Guenther, A., Harley, P., Pressley, S., and Vogel, C.: Flux estimates and oh reaction potential of reactive biogenic volatile organic compounds (BVOCs) from a mixed northern hardwood forest, Atmos. Environ., 41, 5479-5495, 2007.

Park, K., Park, J. Y., Kwak, J. H., Cho, G. N., and Kim, J. S.: Seasonal and diurnal variations of ultrafine particle concentration in urban Gwangju, Korea: Observation of ultrafine particle events, Atmos. Environ., 42, 788-799, 2008.

Petäjä, T., Kerminen, V.-M., Dal Maso, M., Junninen, H., Koponen, I. K., Hussein, T., Aalto, P. P., Andronopoulos, S., Robin, D., Hämeri, K., Bartzis, J. G., and Kulmala, M.: Submicron atmospheric aerosols in the surroundings of Marseille and Athens: physical characterization and new particle formation, Atmos. Chem. Phys., 7, 2705-2720, doi:10.5194/acp-7-27052007, 2007.

Petäjä, T., Mauldin, III, R. L., Kosciuch, E., McGrath, J., Nieminen, T., Paasonen, P., Boy, M., Admov, A., Kotiaho, T., and Kulmala, M.: Sulfuric acid and $\mathrm{OH}$ concentrations in a boreal forest site, Atmos. Chem. Phys., 9, 7435-7448, doi:10.5194/acp-97435-2009, 2009.

Pryor, S. C., Barthelmie, R. J., Sørensen, L. L., McGrath, J. G., Hopke, P., and Petäjä, T.: Spatial and vertical extent of nucleation events in the Midwestern USA: insights from the Nucleation In ForesTs (NIFTy) experiment, Atmos. Chem. Phys., 11, 16411657, doi:10.5194/acp-11-1641-2011, 2011.

Qian, S., Sakurai, H., and McMurry, P. H.: Characteristics of regional nucleation events in urban East St. Louis, Atmos. Environ., 41, 4119-4127, 2007.

Raes, F. and Janssens, A.: Ion-induced aerosol formation in a $\mathrm{H}_{2} \mathrm{O}$ $\mathrm{H}_{2} \mathrm{SO}_{4}$ system - I. Extension of the classical theory and search for experimental evidence, J. Aerosol. Sci., 16, 217-227, 1985.

Rinne, H. J. I., Guenther, A. B., Greenberg, J. P., and Harley, P. C.: Isoprene and monoterpene fluxes measured above Amazonian rainforest and their dependence on light and temperature, Atmos. Environ., 36, 2421-2426, 2002.

Saathoff, H., Naumann, K. H., Schnaiter, M., Schock, W., Mohler, O., Schurath, U., Weingartner, E., Gysel, M., and Baltensperger, U.: Coating of soot and $\left(\mathrm{NH}_{4}\right)_{2} \mathrm{SO}_{4}$ particles by ozonolysis products of alpha-pinene, J. Aerosol Sci., 34, 1297-1321, 2003.

Sjogren, S., Gysel, M., Weingartner, E., Alfarra, M. R., Duplissy, J., Cozic, J., Crosier, J., Coe, H., and Baltensperger, U.: Hygroscopicity of the submicrometer aerosol at the high-alpine site Jungfraujoch, 3580m a.s.1., Switzerland, Atmos. Chem. Phys., 8, 5715-5729, doi:10.5194/acp-8-5715-2008, 2008.

Spirig, C., Guenther, A., Greenberg, J. P., Calanca, P., and Tarvainen, V.: Tethered balloon measurements of biogenic volatile organic compounds at a boreal forest site, Atmos. Chem. Phys., 4, 215-229, doi:10.5194/acp-4-215-2004, 2004.
Stanier, C. O., Khlystov, A. Y., and Pandis, S. N.: Nucleation events during the Pittsburgh air quality study: Description and relation to key meteorological, gas phase, and aerosol parameters, Aerosol. Sci. Tech., 38, 253-264, 2004.

Surratt, J. D., Kleindienst, T. E., Edney, E. O., Offenberg, J. H., Lewandowski, M., Jaoui, M., and Seinfeld, J. H.: Effect of acidity on secondary organic aerosol formation from isoprene, Environ. Sci. Technol., 41, 5363-5369, 2007.

Venzac, H., Sellegri, K., Laj, P., Villani, P., Bonasoni, P., Marinoni, A., Cristofanelli, P., Calzolari, F., Fuzzi, S., Decesari, S., Facchini, M.-C., Vuillermoz, E., and Verza, G. P.: High, frequency new particle formation in the Himalayas, Proc. Natl. Acad. Sci. USA, 105, 15666-15671, 2008.

Virkkula, A., Van Dingenen, R., Raes, F., and Hjorth, J.: Hygroscopic properties of aerosol formed by oxidation of limonene, alpha-pinene, and beta-pinene, J. Geophys. Res., 104, 35693579, 1999.

Watson, J. G., Chow, J. C., Park, K., and Lowenthal, D. H.: Nanoparticle and ultrafine particle events at the Fresno supersite, J. Air Waste Manage. Assoc., 56, 417-430, 2006.

Weber, R. J., Sullivan, A. P., Peltier, R. E., Russell, A., Yan, B., Zhen, M., de Gouw, J. Warneke, C., Brock, C., Holloway, J. S., Atlas, E. L., and Edgerton, E.: A study of secondary organic aerosol formation in the anthropogenicinfluenced southeastern United States, J. Geophys. Res., 112, D13302, doi:10.1029/2007JD008408, 2007.

Willeke, K.: Temperature dependence of particle slip in a gaseous medium, J. Aerosol Sci., 7, 381-387, 1976.

World Health Organization: Global solar UV index: A practical guide, Switzerland, 2002.

Wu, Z., Hu, M., Liu, S., Wehner, B., Bauer, S., Ma $\beta$ ling, A., Wiedensohler, A., Petäjä, T., Dal Maso, M., and Kulmala, M.: New particle formation in Beijing, China: Statistical analysis of a 1-year data set, J. Geophys. Res., 112, D09209, doi:10.1029/2006JD007406, 2007.

Yu, F. and Turco, R. P.: Ultrafine aerosol formation via ion-mediated nucleation, Geophys. Res. Lett., 27, 883-886, 2000.

Yue, D., Hu, M., Wu, Z., Wang, Z., Guo, S., Wehner, B., Nowak, A., Achtert, P., Wiedensohler, A., Jung, J., Kim, Y. J., and Liu, S.: Characteristics of aerosol size distributions and new particle formation in the summer in Beijing, J. Geophys. Res., 114, D00G12, doi:10.1029/2008JD010894, 2009.

Yue, D. L., Hu, M., Zhang, R. Y., Wang, Z. B., Zheng, J., Wu, Z. J., Wiedensohler, A., He, L. Y., Huang, X. F., and Zhu, T.: The roles of sulfuric acid in new particle formation and growth in the mega-city of Beijing, Atmos. Chem. Phys., 10, 4953-4960, doi:10.5194/acp-10-4953-2010, 2010.

Zhang, K. M. and Wexler, A. S.: A hypothesis for growth of fresh atmospheric nuclei, J. Geophys. Res., 107, 4577, doi:10.1029/2002JD002180, 2002.

Zhang, R., Wang, L., Khalizov, A. F., Zhao, J., Zheng, J., McGraw, R. L., and Molina, L. T.: Formation of nanoparticles of blue haze enhanced by anthropogenic pollution, Proc. Natl. Acad. Sci. USA, 106, 17560-17654, 2009. 